\title{
A FAMÍLIA E O ALUNO COM NECESSIDADE EDUCACIONAL ESPECIAL NO ESPAÇO DA ESCOLA
}

MAURA CACILDA CABRAL MACHADO

ORIENTADORA: RUTE NOGUEIRA DE MORAIS BICALHO 


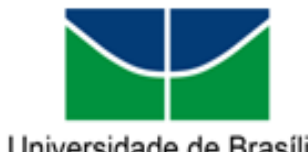

Universidade de Brasilia

Universidade de Brasília - UnB

Instituto de Psicologia - IP

Departamento de Psicologia Escolar e do Desenvolvimento - PED

Programa de Pós-Graduação em Processos de Desenvolvimento Humano e Saúde PGPDS

MAURA CACILDA CABRAL MACHADO

\section{A FAMÍLIA E O ALUNO COM NECESSIDADE EDUCACIONAL ESPECIAL NO ESPAÇO DA ESCOLA}

Monografia apresentada ao Curso de Especialização e Desenvolvimento Humano, Educação e Inclusão Escolar da Faculdade UAB/UNB - Pólo de Ceilândia.

Orientadora: Rute Nogueira de Morais Bicalho 
TERMO DE APROVAÇÃO

MAURA CACILDA CABRAL MACHADO

\section{A FAMÍLIA E O ALUNO COM NECESSIDADE EDUCACIONAL ESPECIAL NO ESPAÇO DA ESCOLA}

Monografia aprovada como requisito parcial para obtenção do grau de Especialista do Curso de Especialização em Desenvolvimento Humano, Educação e Inclusão Escolar - UAB/UnB. Apresentação ocorrida em /__ / 2011

RUTE NOGUEIRA DE MORAIS BICALHO

ORIENTADORA

EXAMINADOR

MAURA CACILDA CABRAL MACHADO

BRASÍLIA/ 2011 


\section{DEDICATÓRIA}

A todas as mães, que assim como eu,sonham com a efetiva inclusão escolar e lutam pela qualidade de vida de seus filhos com necessidades educacionais especiais. 


\section{AGRADECIMENTOS}

À orientadora Rute Bicalho pela sua constante presença e dedicação no acompanhamento deste trabalho.

Ao meu filho João Marcos com Síndrome de Down, minha maior inspiração. Às minhas filhas, Talita e Meline, pela dedicação ao irmãozinho. Ao meu genro, Lincoln, por sua demonstração de carinho ao João Marcos.

Aos meus pais que mesmo distantes se fazem presentes.

Ao meu irmão e as minhas irmãs, em especial a Miosete, pela sua presença nos primeiros dias de vida de meu filho.

Ao Marcelo, pai de meu filho, por ter proporcionado ao "Joãozinho" momentos de recreação nas horas mais cruciais desta pesquisa.

Aos meus cunhados, Celso, Aguiar e Robério, pelo carinho dado ao João Marcos.

À Cássia, pelos cuidados dedicados ao João Marcos nos últimos seis anos.

Aos professores de João Marcos, em especial ao professor Sidney, por sua dedicação ao trabalhar com meu filho.

Aos amigos que têm interesse pelo tema inclusão escolar e em especial à professora Célia pelo carinho dado quando fui a campo.

Às mães, às professoras e aos alunos pela contribuição dada nas entrevistas.

Aos colegas de curso e aos tutores que estiveram presente.

A todos os mestres que contribuíram com seus textos para a construção dos debates na plataforma do curso.

A SEEDF e a UnB, pela oportunidade deste curso de especialização. 
"Se, na vida afetiva, a família precisou exercer mais a Pedagogia para escoltar seus filhos, agora na vida escolar, os professores precisarão aplicar mais a Psicologia para exercerem a Pedagogia sobre seus diferentes/semelhantes alunos".

Albertina de Mattos Chraim 


\section{RESUMO}

É na família que a criança tem as suas primeiras interações sociais. Quando na infância, ela é inserida no contexto escolar, iniciando relações sociais mais independentes e fora do seio familiar. No ambiente da escola, a criança tem possibilidades de encontrar-se com a diversidade e aprender com o outro por meio das trocas de experiências e de vivências. Nesse sentindo, este trabalho visa compreender a importância do espaço escolar no cotidiano das crianças, particularmente dos alunos com necessidade educacional especial, enfatizando a participação de suas famílias no processo de inclusão. Participaram da pesquisa 3 alunos inclusos no ensino fundamental nas séries iniciais, 4 mães e 4 professoras. A pesquisa qualitativa foi utilizada para viabilizar os instrumentos de coleta de dados e os procedimentos de análises, em uma perspectiva de aproximar o pesquisador e os pesquisados. Foram realizadas, com todos os participantes, entrevista semiestruturada e observação do contexto escolar. A partir das falas dos participantes, os resultados foram organizados em cinco categorias e discutidos à luz da literatura da área sobre inclusão. Os alunos, as mães e os professores falaram sobre as dificuldades enfrentadas no processo de inclusão escolar e apontaram os avanços conquistados nos últimos anos, ressaltando o valor da inclusão na vida dos alunos e a importância da participação da família no espaço escolar em uma perspectiva de promover o desenvolvimento dos alunos especiais no que concerne a interação social e a aprendizagem. A pesquisa traz alguns pontos relevantes da inclusão escolar pertinente a presença e a participação da família e contribui para as questões inerentes ao processo de ensino aprendizagem do aluno especial no interior da escola.

Palavras-chave: Inclusão Escolar, Espaço Escolar, Família, Aluno com Necessidade Educacional Especial. 


\begin{abstract}
Children have their first social interactions in the family. In the childhood they are inserted at school context, beginning the most independent and social relationships outside the family. At school environment children have opportunities to find diversity and learn with each other through exchanges of experiences. Thus, this work aims to understand the importance of environment school in the daily children lives, particularly students with special need educational, emphasizing the participation of their families in the process of inclusion. The participants included three students of elementary schools in the initial series, four mothers and four teachers. Qualitative research was used to make possible the data collection instruments and procedures of analysis in a closer perspective of the researcher and the researched. All participants answered a semi structured interview and the school context was observed. From the speech of the participants, the results were organized into four categories and discussed based of the literature on inclusion. Students, mothers and teachers spoke about the difficulties towards of process of school inclusion, pointing out the advances made in recent years, to emphasize the importance of inclusion in students' lives and the importance of family involvement at school from the perspective of promoting the development of special students regarding social interaction and learning. The research offers some points relevant to developing educational inclusion of students, to help with issues related to teaching and learning process for the special student at school.
\end{abstract}

Keywords: Inclusion School, School Space, Family, Students with Special Educational Need. 


\section{SUMÁRIO}

APRESENTAÇÃO .................................................................................... 01

I - FUNDAMENTAÇÃO TEÓRICA.

1.1- Breve histórico e bases legais do processo de inclusão na educação de alunos com necessidades educacionais especiais

1.2- A interação social para os processos de desenvolvimento

1.3- A importância do espaço escolar para os alunos com necessidades educacionais especiais

1.4- A participação da família e da escola no processo de inclusão

II - OBJETIVOS

III - METODOLOGIA

3.1- Fundamentação Metodológica

3.2- Contexto de pesquisa

3.3- Participantes da pesquisa

3.4- Materiais e Instrumentos utilizados

3.5- Procedimentos de Construção de Dados

3.6- Procedimentos de Análise de Dados

IV - RESULTADOS E DISCUSSÃO.

4.1- A inclusão escolar e o encontro das leis

4.2- $\quad$ O espaço escolar como promotor de desenvolvimento para o aluno especial

4.3- Família: a presença da mãe na escola

4.4- As dificuldades e os avanços no processo de inclusão escolar

V - CONSIDERAÇÕES FINAIS

REFERÊNCIAS

APÊNDICES.

Apêndice A - Roteiro de entrevista semiestruturada aplicada ao professores

Apêndice B.- Roteiro de entrevista semiestruturada aplicada as famílias

Apêndice C - Roteiro de entrevista semiestruturada aplicadas ao ANNEs

Apêndice D - Roteiro de Observação

ANEXOS

Anexo A - Carta de Apresentação

Anexo B - Termo de Consentimento Livre e esclarecido

Anexo C- Transcrição das entrevistas 


\section{LISTA DE QUADROS}

Quadro 1 - Participantes da Pesquisa.......................................... 23 


\section{APRESENTAÇÃO}

O mundo moderno não é aquele composto de pessoas que investem somente em tecnologia e ciência, mas é também aquele que tem pessoas capazes de investir no campo social, de saber cuidar de todos que nele vivem, de trazer para o convívio tantas outras pessoas, que de uma forma ou de outra, estão excluídas socialmente. capazes de estabelecer um diálogo com todos os segmentos da sociedade, na tentativa de construir novas e diferentes condutas favoráveis à diversidade humana.

Estamos vivendo momentos importantes no cenário mundial a respeito dos direitos humanos com foco na inclusão. Em função disso, surgem espaços na sociedade para atender as necessidades de determinados grupos de pessoas que buscam condições para sua sobrevivência. Neste cenário, destaca-se a escola como lugar privilegiado e democrático que visa, além do processo de ensino-aprendizagem, o compartilhamento de experiências e oportuniza o encontro e a convivência entre as diferenças.

A maior expectativa no espaço escolar é promover oportunidade e permitir que a comunidade participe e atue de maneira a colaborar para o desenvolvimento pleno dos alunos, inserindo-os socialmente. Neste quadro, encontramos o aluno com necessidade educacional especial (ANEE) e a sua família que buscam permanentemente o respeito por seus direitos garantidos por lei.

Sabemos que o processo de inclusão dá-se de maneira constante e gradual, fundamentado em leis que foram sendo modificadas ao longo do tempo, na tentativa de assegurar o direito, a demanda e o interesse de grupos de pessoas, que unidos deram um novo enfoque à questão da inclusão, sobretudo à inclusão escolar, foco deste trabalho. Acreditamos assim, ser necessário pesquisar sobre o papel do espaço escolar na vida da família e dos alunos com necessidade educacional especial, no modelo de escola inclusiva que surge com uma proposta de promover a igualdade de oportunidade a todos.

É importante considerar que a escola reflete a sociedade em que está inserida e, muitas vezes, ela reproduz modelos pedagógicos que não atendem 
ao interesse da comunidade, podendo ser um dos fatores que provoca o afastamento da família do espaço escolar. Esse afastamento pode acentuar ainda mais a exclusão. A participação ativa da família no âmbito escolar pode dar novos rumos à escola e contribuir para a permanência e o desenvolvimento dos alunos, principalmente, os que têm necessidade educacional especial. Nesta perspectiva de inclusão, o espaço da escola pode promover o encontro de novas relações e trocas de experiências, dando oportunidade a todos de conviver com as diferenças e aprender com elas. É importante lembrar que é no seio familiar que a criança tem seu primeiro contato com o mundo. A família é responsável primeira pelo encontro da criança com a escola. Nesse sentido, visando promover a parceria família/escola, esta deverá incluir atividades pedagógicas que ampliam a participação e a presença de todos, principalmente a presença da mãe que, na maioria dos casos, acompanha o filho na sua vida escolar.

Considerando a importância do espaço escolar na vida dos alunos com necessidades educacionais especiais e de sua família, esta pesquisa destaca a escola como espaço potencial para a acessibilidade de todos, lugar onde as relações sociais acontecem rotineiramente com vistas a possibilitar a participação da comunidade escolar no processo de ensino-aprendizagem e desenvolvimento dos alunos.

A motivação para o estudo dessa temática surge da minha própria experiência enquanto mãe de um menino com Síndrome de Down. Eu percebo a construção paulatina de uma intimidade entre ele e os espaços em que transita e aprendeu a conviver; sobretudo o espaço da escola, no qual a interação com os pares e com os professores está sendo fundamental para o seu desenvolvimento e inserção nos demais espaços sociais.

Além disso, sou professora de Geografia e tenho alguns alunos com necessidade educacional especial. Dessa forma, busquei unir minha área de formação, minha experiência pessoal e profissional para o desenvolvimento deste estudo. Considero a escola um espaço geográfico, do qual gosto de observar o quanto ela pode favorecer as relações sociais voltadas à inclusão. Em outros termos, busco vincular o espaço escolar à escola inclusiva, com o objetivo de apresentar os significados construídos pela família e pelo ANEE sobre a relevância do mesmo em suas vidas. 
Esta pesquisa justifica-se pela necessidade de se criar um espaço escolar efetivamente favorável aos ANEEs,considerando o significado que eles e seus familiares constroem sobre o mesmo. A partir disso, acreditamos ser possível estimular a participação da família e aproximá-la das ações escolares para o processo e progresso da educação inclusiva. Ainda pretendemos apontar os avanços obtidos no processo de ensino-aprendizagem do ANEE e as dificuldades enfrentadas por ele, pela família e pelo professor.

Para tanto, a pesquisa está estruturada da seguinte forma: na fundamentação teórica são apresentados alguns teóricos que trabalham com a inclusão, os quais ajudam a sustentar as questões levantadas aqui. Em seguida, na metodologia de orientação qualitativa, são apresentados 0 percurso da pesquisa, a descrição do contexto, dos participantes e dos instrumentos utilizados. Por último, nos resultados e discussões, são apresentadas as análises das informações apreendidas na interação pesquisador/participante e pesquisador/contexto, com intuito de buscar 0 diálogo sobre inclusão juntamente à família, aos professores e aos alunos com necessidades educacionais especiais. 


\section{I- FUNDAMENTAÇÃO TEÓRICA}

\section{1- Breve histórico e bases legais do processo de inclusão na educação de alunos com necessidades educacionais especiais}

Para compreender melhor a educação voltada para as pessoas com necessidade educacional especial no contexto social brasileiro, é necessário fazer uma retrospectiva do processo de construção da educação especial inclusiva.

As primeiras iniciativas para inclusão no Brasil deram-se em meados do século XIX, com a criação de duas instituições públicas: uma para cegos e a outra para surdos mudos, no Rio de Janeiro. Já em 1926, foi fundado o Instituto Pestalozzi, instituição especializada para atender as pessoas com deficiência mental. Em 1954 foi criada a APAE (Associação de Pais e Amigos dos Excepcionais).

Com a criação da Lei de Diretrizes e Bases da Educação Nacional (LDBEN), Lei no 4.024/61, foi consolidado o direito dos excepcionais à Educação, preferencialmente dentro do sistema geral de ensino. Todavia, dez anos mais tarde, a Lei nº 5.692/71 pouco promoveu a organização de um sistema de ensino capaz de atender às demandas dos alunos com necessidades físicas ou mentais ao decidir tratá-los de modo diferenciado, o que acabou por reforçar o encaminhamento deles às escolas especiais. Nessa direção, no ano de 1973, o Ministério da Educação (MEC) criou o Centro Nacional de Educação Especial (CENESP) que impulsionou ações educacionais voltadas às pessoas com deficiência e às pessoas com superdotação.

Avanços ocorreram com a Constituição Federal de 1988, que apresenta como objetivo fundamental, entre outros, "promover o bem de todos, sem preconceitos de origem, raça, sexo, cor, idade e quaisquer outras formas de discriminação" (art.3ํinciso IV). Define, no artigo 205, a educação como um direito de todos, garantindo o pleno desenvolvimento da pessoa, o exercício da cidadania e a qualificação para o trabalho. No artigo 206, inciso I, estabelece a "igualdade de condição de acesso e permanência na escola”, como um dos 
princípios para o ensino, assegurando ainda o dever do Estado em ofertar atendimento educacional especializado, preferencialmente na rede regular de ensino (art. 208).

Na década de 90, documentos como a Declaração Mundial de Educação para Todos em Jomtien - Tailândia (1990) que tinha como objetivo maior satisfazer as necessidades básicas da aprendizagem de todas as crianças, jovens e adulto, Estatuto da Criança e do Adolescente (1990) e a Declaração de Salamanca (1994) que influenciaram as mudanças ocorridas na educação brasileira, orientam que as pessoas com necessidades educacionais especiais devem ter acesso às escolas comuns, devendo ser integradas dentro de uma perspectiva de pedagogia centralizada na criança, capaz de atender a suas necessidades. Esse pressuposto influenciou a formulação das políticas públicas da educação inclusiva, quando o Brasil optou por um sistema educacional inclusivo. Em 1994, foi publicada a Política Nacional de Educação Especial, responsável por orientar o processo de "integração instrucional" às classes comuns do ensino regular, aqueles que possuíam condições de acompanhar e desenvolver as atividades curriculares.

A atual LDBEN (Lei no. 9.394/96) recomenda que os sistemas de ensino devam assegurar aos alunos, currículo, métodos, recursos e organização específicos para atender às suas necessidades. A Resolução CNE/CEB no 2/2001, no artigo $2^{\circ}$, determina que a escola precisa organizar-se para receber os alunos com necessidades educacionais especiais.

O Decreto no 3.956/2001, que promulgou a Convenção da Guatemala (1999), garante que as pessoas com deficiências têm os mesmos direitos humanos e liberdades fundamentais que as demais pessoas, definindo como discriminação com base na deficiência, toda diferenciação ou exclusão que possa impedir ou anular o exercício dos direitos humanos e de suas liberdades fundamentais.

O Plano Nacional de Educação (PNE, Lei no 10.172/2001) destacou que "o grande avanço que a década da educação deveria produzir seria a construção de uma escola inclusiva que garanta o atendimento à diversidade humana".

A Lei n 10.436/02 reconheceu a Língua Brasileira de Sinais como meio legal de comunicação e expressão. A Portaria n 2.678/02 aprovou diretriz e 
normas para o uso, o ensino, a produção e a difusão do Sistema Braille em todas as modalidades de ensino. No ano de 2003, o Ministério da Educação criou o Programa Educação Inclusiva, com objetivo de promover a formação de gestores e educadores nos municípios brasileiros para garantir o direito de acesso de todos à escolarização, à organização do atendimento educacional especializado e à promoção da acessibilidade.

Em 2007 foi lançado o Plano de Desenvolvimento da Educação (PDE), que tem por eixos a acessibilidade arquitetônica dos prédios escolares, a implantação de salas de recursos e a formação docente para o atendimento educacional especializado, reafirmando as orientações dos demais documentos já citados, visando garantir a necessidade de inclusão escolar das pessoas com deficiência. Porém, pode-se notar, no âmbito do Distrito Federal, que ainda há muitas escolas de difícil acessibilidade, muitos prédios velhos, precisando de reformas para atender às necessidades dos alunos com deficiência de todas as ordens.

Finalmente, o Decreto nํㅜ 6.094/2007 estabeleceu a garantia do acesso à permanência no ensino regular $e$ do atendimento às necessidades educacionais especiais dos alunos, fortalecendo a inclusão educacional nas escolas públicas.

É inegável e notório que muitos avanços ocorreram nas leis brasileiras, desde meados do século XIX aos dias atuais, pertinentes ao ensino especial com foco na educação inclusiva. As conquistas alcançadas durante os últimos anos decorreram do aumento da conscientização da sociedade em proteger os direitos das minorias, entre as quais estão as pessoas com necessidades especiais. Ninguém pode ser privado dos seus direitos por ser diferente ou por ter uma necessidade especial.

É importante ressaltar que para a implementação efetiva das leis citadas acima, resultando no processo de inclusão de fato e de direito, faz-se necessária maior sensibilização da sociedade rumo à cobrança das conquistas adquiridas pelas pessoas com necessidades especiais, dentro de uma perspectiva de inclusão social. Permitir aos cidadãos, especialmente aos que possuem necessidade especial, oportunidade de conviver em grupo respeitosamente. É dever de todos. E sobre esse assunto Simão (2010) discorre: 
Garantir o direito à educação, ainda significa um longo caminho a ser percorrido, e alcançar um atendimento de qualidade a esta população que vem crescendo, com luta, pela sobrevivência e participação em todos os setores da sociedade, requer um grande amadurecimento de todos, além de otimismo em relação ao nosso futuro (pois tem aqueles que acreditam que o mundo está por acabar), e também habilidades nas relações interpessoais (SIMÃO, 2010, p.18).

O paradigma da inclusão social está relacionado aos avanços tecnocientíficos que a sociedade obteve nas últimas décadas e, sobretudo, às conquistas alcançadas no cenário mundial a respeito dos direitos humanos. Dentre elas, destacamos a escola inclusiva, que traz os alunos com necessidade especial para as escolas regulares, proporcionando a eles e aos demais alunos o convívio com as diferenças que estão intrínsecas em toda a sociedade.

Apesar dos avanços na legislação brasileira e considerando que o Brasil é um país democrático com grande diversidade cultural, ainda é um enorme desafio o respeito e a aceitação das diferenças humanas. Autores, especialmente da Psicologia, destacam a importância das relações baseadas nas diferenças, visando um desenvolvimento salutar; assunto a ser abordado no tópico seguinte deste trabalho.

\section{2- $\quad$ A interação social para os processos de desenvolvimento}

Por interação social entende-se o processo de influência mútua que as pessoas exercem entre si. (PILETTI, 1991, p.80). A partir desse entendimento, devemos defender a educação inclusiva no processo de ensino-aprendizagem, na expectativa de gerar relações mais respeitosas no espaço da escola e da comunidade, para que os direitos de igualdade e de oportunidade sejam reverenciados na ação educacional,visando o princípio da dignidade do ser humano, onde qualquer pessoa é digna e merecedora do respeito de seus semelhantes. 
Nesse aspecto, Pacheco afirma que "as escolas inclusivas consideram a aprendizagem como um processo social em que a interação social tem um papel central para facilitar a aprendizagem" (PACHECO, 2007, p. 148). Partindo da ideia sócio-interacionista, as pessoas com necessidades especiais também necessitam do convívio com o outro para desenvolver-se plenamente. A interação social possibilita o encontro das diferenças, promovendo um maior desenvolvimento das pessoas com necessidade especial, como também o desenvolvimento das outras pessoas que terão oportunidade de conviver com a diferença, enriquecendo suas relações sociais e lidando com a diversidade.

De acordo com Rego (2001, p. 56), "Vigotsky atribui enorme importância ao papel da interação social no desenvolvimento do ser humano". É na relação com o outro que o ser humano aprende, ensina e troca experiência, em uma perspectiva de se inserir em determinado espaço social, possibilitando um maior aprendizado nesse contato com o outro, obtendo um desenvolvimento humano pautado na visão de grupo e na importância de viver em sociedade, comungando ideias com intuito de promover o acesso de todos nas questões pertinentes a eles. Para Vigotsky:

Organismo e meio exercem influência recíproca, portanto o biológico e o social não estão dissociados. Nesta perspectiva, a premissa é de que o homem constitui-se como alguém que transforma e é transformado nas relações produzidas em uma determinada cultura (VYGOTSKY, apud REGO, 2001, p.93).

Para Rego (2001, p. 71), "O desenvolvimento pleno do ser humano depende do aprendizado que realiza em um determinado grupo cultural, a partir da interação com os outros indivíduos da sua espécie". A escola é um ambiente propício para promover o encontro de novas relações e trocas de experiências, dando oportunidade a todos de conviver com as diferenças e aprender com elas.

Tunes, Tacca e Martinez fazem referência à perspectiva históricocultural, relacionando os processos de aprendizagem escolar com 0 desenvolvimento do indivíduo no aspecto social: 
A perspectiva histórico-cultural de desenvolvimento humano tem salientado a dimensão social da aprendizagem escolar, dimensão pouco considerada em outros enfoques teóricos da aprendizagem. O reconhecimento do caráter histórico e cultural da constituição da psique humana e, especialmente, o papel essencial que é conferido ao Outro nos processos de aprendizagem e desenvolvimento na ontogênese remetem à compreensão da aprendizagem escolar não apenas como um processo do sujeito individual, mas como um processo de natureza social (TUNES, TACCA \& MARTINEZ, 2006, p. 109).

Dentre os conceitos fundamentais que compõem a teoria de Vigotski, destacamos a zona de desenvolvimento proximal:

A distância entre aquilo que a criança é capaz de fazer de forma autônoma (nível de desenvolvimento real) e aquilo que ela realiza em colaboração com os outros elementos de seu grupo social (nível de desenvolvimento potencial). (REGO, 2001, p. 73).

Para Tunes, Tacca e Martinez "o conceito de zona de desenvolvimento próxima de Vigotski ilustra a concepção de que os processos de desenvolvimento e aprendizagem humanos são essencialmente sociais" ( $p$. 109).

O processo de aprendizagem escolar baseado na teoria histórico-cultural ultrapassa a natureza individual do sujeito, transportando-o para o convívio com seus pares do qual é visto como um ser que emerge na sociedade. Daí a importância da inclusão escolar na aprendizagem e no desenvolvimento do aluno com necessidade educacional especial.

Fundamentado em Piaget, Goulart discorre sobre importância do social na aprendizagem da criança:

A descentração necessária para se chegar às operações não se baseia apenas num universo físico, mas também num universo social; isto significa que a criança passa a elaborar o 
seu conhecimento do mundo levando em conta os sujeitos com os quais convive e que são, ao mesmo tempo, diferentes e semelhantes a ela (GOULART, 1983, p.63).

A teoria de aprendizagem de Piaget relaciona o desenvolvimento cognitivo da criança ao afetivo social, a criança recebe influência do meio que interfere na sua aprendizagem. Mesmo dividindo a teoria em etapas de desenvolvimento, Piaget menciona o meio social como um fator importante no desenvolvimento cognitivo da criança.

Os estudos de Educação em Psicologia tendem a incluir o desenvolvimento da criança numa perspectiva social, onde as pessoas necessitam do meio para aprenderem o convívio com o outro. E esse meio é vivido também no espaço da escola que é um lugar privilegiado para construir uma sociedade participativa, autônoma, cidadã e transformadora da realidade.

\section{3- A importância do espaço escolar para os alunos com necessidades educacionais especiais}

Inicialmente, o espaço escolar é compreendido pelos aspectos físicos da escola, como por exemplo: as salas de aula, a sala da direção, a secretaria, o pátio, a biblioteca, os banheiros, a quadra de esportes, entre outros. Porém é necessário perceber que o mesmo faz parte de outra dimensão que é pautada no convívio e no cotidiano de todos os envolvidos no interior da escola. $O$ espaço escolar que ao mesmo tempo perpassa o espaço físico construído pelo homem no decorrer de sua história, também nos faz refletir sobre outro que emana das relações sociais existentes na comunidade vigente.

Por isso, faz-se necessário pesquisar sobre o papel do espaço escolar na vida das famílias e dos alunos com necessidades educacionais especiais e suas perspectivas; a formação continuada do professor, como também discutir outras limitações que surgem nesse espaço, impedindo que a inclusão escolar aconteça de maneira adequada.

Amaral aborda a concepção de escola do ponto de vista de Wallon: "A escola é um meio onde convivem diferentes grupos e onde a criança exercita suas potencialidades, transformando ou confirmando a imagem que traz de si, 
da vivência com a família" (AMARAL, 2002, p.58). Essa concepção de meio atribui à escola uma maior responsabilidade, uma vez que ela é percebida como um meio funcional, onde os grupos são constituídos de maneiras variadas que podem se juntar ou se opor ao sistema educacional em vigor.

Portanto, a escola é um ambiente que propicia vivências; nela o indivíduo se forma constantemente a partir da interação com o outro, em uma relação recíproca. Nela também se aprende a disciplina e a organização, nas relações de conflito pautadas por aceitação e divergência.

Sobre o espaço Carlos coloca que: "O espaço é construído em função de um tempo e de uma lógica que impõe comportamentos, modos de uso, o tempo e a duração do uso" (CARLOS, 1996, p.24). Todas as relações humanas acontecem em determinado tempo e espaço onde certos grupos de pessoas podem manifestar as suas necessidades e seus ideais, modificando o espaço e construindo sua vida por meio de outros grupos sociais.

Ainda que as pessoas façam parte de um grupo, elas não são iguais, cada uma tem uma visão diferente de pensar o mundo, suas crenças não são as mesmas. No entanto, quando estão em grupo, se fortalecem em busca de um objetivo em comum, por uma vida melhor para si e para os demais. É nesse contexto que destacamos o espaço escolar no que diz respeito às relações pautadas na diversidade. E nesse espaço encontramos todos os alunos, inclusive os têm necessidades educacionais especiais, que vêem no espaço escolar uma oportunidade de serem inseridos socialmente, de exercerem a sua cidadania. A família também coloca as suas expectativas na escola ao ver seus filhos inseridos no processo educacional, onde terão maiores possibilidades de se desenvolverem.

Observando os alunos com necessidades educacionais especiais na escola inclusiva, juntamente com a sua família, o espaço escolar pode representar um papel essencial na vida cotidiana deles, contribuindo para a inserção na sociedade. De acordo com Rego (2001, p.60), para Vigotsky "o desenvolvimento do sujeito humano se dá a partir das constantes interações com o meio social em que vive, já que as formas psicológicas mais sofisticadas emergem da vida social".

O espaço é entendido como espaço social, vivido, em estreita correlação com a prática social, como relatado por Correa (1995, p. 28): "em realidade o 
espaço organizado pelo homem desempenha um papel na sociedade, condicionando-a, compartilhando do complexo processo de existência e reprodução social". Neste contexto destaca-se o espaço escolar, que oportuniza a todos os envolvidos a conviver com as diferenças e compartilhar experiências.

Para Raposo (2006, p.2), "o espaço escolar representa concretamente um dos cenários de construção e de mudanças e deve ser compreendido em sua complexidade e em suas possibilidades relacionadas a cada sujeito e à sua sociedade". Compete aos professores e aos demais envolvidos na educação escolar aproveitarem o espaço da escola para construir uma sociedade mais justa e democrática, pautado no direito de todos de participar ativamente do meio onde vive.

A escola, em sua essência, é um ambiente público localizado em outro ambiente, também público, que é o espaço da comunidade onde as pessoas compartilham interesses comuns. Por isso, faz-se necessário debater, compreender a dinâmica do espaço escolar, numa perspectiva de atender e inserir toda a comunidade nesse espaço construído socialmente, que emerge no cotidiano das pessoas, no modo de vida, no relacionamento com o outro. Nessa perspectiva, afirma Carvalho (2002):

Trata-se, portanto, de espaço plural, extremamente complexo, impregnado de regras, de valores (nem sempre consensuais) e de muitos sentimentos contraditórios quanto às funções políticas e sociais das escolas. Inúmeras e diversas são as expectativas da sociedade, das famílias, dos alunos, de toda a comunidade escolar, interferindo direta ou indiretamente no dia-a-dia das escolas (CARVALHO, 2002, p.180).

O espaço escolar também é visto na sua pluralidade, exercendo funções sociais das mais diversas: em princípio, transmitindo conhecimento e em seguida, transformando a sociedade. Mas nem sempre a escola é transformadora, ao contrário, muitas vezes ela mantém velhos modelos sociais de exclusão. Com a conquista da inclusão escolar, garantida na legislação, 
acreditamos que as escolas darão um passo largo, no que se refere às mudanças sociais baseadas no direito de igualdade para todos.

Percebe-se que os indivíduos de uma determinada comunidade, mesmo objetivando alcançar metas sociais em comum (estudar, ser bem sucedido na profissão, educar seus filhos, ter qualidade de vida, entre outras aspirações), apresentam-se de diferentes maneiras, seja na sua anatomia ou na visão de mundo. Essa diversidade na sociedade permite a troca de experiências e a construção de um novo relacionamento social com vista no desenvolvimento humano.

Neste quadro de diversidade, destacamos as pessoas com necessidades especiais, que também almejam ser respeitadas e acolhidas dentro dos grupos socialmente estabelecidos, em especial na comunidade escolar que é o espaço mais próximo delas, logo após da família.

A Constituição Federal de 1988 retratou as conquistas relativas à educação das pessoas com deficiência, sendo uma aliada nessa reconstrução da escola. Ela não adjetivou a educação quando garantiu a todos esse direito. Portanto, as escolas brasileiras já deveriam estar atendendo a nossos princípios constitucionais há muito tempo, não excluindo nenhum aluno de suas salas de aula de ensino regular (MACHADO, 2009, p.75).

Mesmo tendo a Constituição Federal de 1988 como uma grande aliada na conquista de uma escola inclusiva, o processo de inclusão nos primeiros anos após a constituição ocorreu lentamente. A Lei de Diretrizes e Bases da Educação Nacional no 9.394/96 após promover debates com os segmentos envolvidos no sistema educacional, pautados na constituição, intensificou o processo de inclusão escolar.

Até o momento muito decretos foram aprovados numa perspectiva de aceleramento no que diz respeito à inclusão dos alunos com necessidades especiais. Sem dúvida, nos últimos anos, houve um avanço considerável no processo de inclusão nas escolas brasileiras, mesmo em passos lentos a educação está avançando no que concerne à escola inclusiva. 
Entre 1998 a 2006, houve crescimento de 640\% das matrículas em escolas comuns (inclusiva) e de $28 \%$ em escolas de classes especiais. Entre 2002 e 2006, houve crescimento de 194\% das matrículas inclusivas, com crescimento de $17 \%$ em escola com apoio pedagógico especializado e $208 \%$ em escola sem apoio pedagógico especializado (MEC/INEP, 2007). Segundo as estatísticas, o crescimento de alunos com necessidade especial matriculados em escolas inclusivas entre 1998 a 2006 é considerável e perceptível.

Para continuar os avanços na construção de escolas inclusivas é imprescindível que o sistema de ensino acolha cada aluno com necessidade especial de maneira comprometida, questione a acessibilidade, a permanência e, principalmente o seu progresso. Carvalho (2002) coloca de maneira pertinente a importância de um mundo inclusivo:

Um mundo inclusivo é um mundo no qual todos têm acesso às oportunidades de ser e de estar na sociedade de forma participativa; onde a relação entre $o$ acesso às oportunidades $e$ as características individuais não são marcadas por interesses econômicos, ou pela caridade pública (CARVALHO, 2002, p.111).

Nesta perspectiva é necessário compreender a importância do significado da escola para os alunos com necessidade educacional especial. A escola pode representar para eles o vínculo social marcante, as interações ocorrem densamente por ser um lugar de ensino aprendizagem, um lugar onde há uma rotina, onde o contato com o outro se dá cotidianamente.

Mesmo sendo o homem um ser social, cada indivíduo é singular. Mizukami coloca que:

Para Rogers a realidade é um fenômeno subjetivo, pois o ser humano reconstrói em si o mundo exterior, partindo de sua percepção, recebendo os estímulos, as experiências, atribuindo-Ihes significado. Em cada indivíduo, há uma consciência autônoma e interna que the permite significar e optar, e a educação deverá criar condições para que essa consciência se preserve e cresça (MIZUKAMI, 2001, p.41). 
Se a realidade é subjetiva para cada ser humano, isso significa que ela também é para a pessoa com necessidade especial, ainda que uma pessoa apresente comportamento diferente do padrão socialmente construído, ela é, antes de tudo, um ser humano dotado de pensamento, sentimento e inteligência.

A escola inclusiva representa para os alunos especiais um lugar de interação com o grupo de colegas, com os professores, com a comunidade escolar, promovendo o seu desenvolvimento pleno como ser humano. A inclusão defende que a escola deve atender aos alunos especiais, levando em consideração o potencial de cada um, numa perspectiva de inserí-los no contexto social. A escola, como o segundo espaço de socialização de uma criança, tem um papel fundamental na determinação do lugar que passará a ocupar junto à família $e$, por consequência no seu processo de desenvolvimento.

É fundamental que a escola inclusiva acolha todos os alunos com vista na melhoria das relações sociais, dentro e fora do espaço escolar. É tempo de incluir todas as pessoas na sociedade, é tempo de transformar-se para transformar a sociedade que necessita de mudanças urgentes. Apesar dos avanços, há muitas pessoas fora do processo de inclusão social.

\section{4- A participação da família e da escola no processo de inclusão}

A família é uma instituição social que se inter-relaciona com outras instituições, sendo responsável pelo processo de socialização da criança. Sobre a família Szymanski coloca que: "É na família que a criança encontra os primeiros "outros" e, por meio deles, aprende os modos humanos de existir seu mundo adquire significado e ela começa a constituir-se como sujeito". (SZYMANSKI, 2010, p.22). Ao receber o aluno, o professor deve respeitar o aprendizado que a criança adquiriu com a sua família, promovendo as trocas de experiências entre eles no intuito de valorizar a individualidade de cada um e a diversidade do grupo. 
$\mathrm{Na}$ perspectiva da criança com necessidade educacional especial, a família e a escola são instituições que oportunizam maiores possibilidades de inclusão social, sobre esse assunto Ogama e Tanaka colocaram:

A família é peça fundamental no processo de desenvolvimento, socialização e integração do indivíduo portador de deficiência mental. Nesse sentido é importante que as instituições de atendimento a essa população desenvolvam trabalhos que possibilitem o vínculo com a família, para que a mesma possa colaborar nesse processo, através da continuidade das atividades realizadas pela escola, no lar (OGAMA \& TANAKA, 2003, p.35).

Por meio da família, a escola terá mais informações sobre seus alunos. Para isso a escola deve fazer um planejamento voltado para a participação ativa da família dentro e fora das dependências da escola. As mediações entre a família e a escola propiciam trocas de experiências que beneficiarão os alunos.

Segundo Pacheco (2007, p. 163), "os pais conhecem seus filhos melhor do que qualquer pessoa e possuem informações que podem ter influência fundamental em sua educação". A educação inclusiva implica em ações pedagógicas voltadas para $\mathrm{O}$ atendimento do aluno com necessidade educacional especial que não se restrinja à relação professor-aluno, mas que seja idealizado no contexto da comunidade escolar.

Ainda sobre este tema, Carvalho (2000) explica que:

Examinar a prática pedagógica objetivando identificar as barreiras para a aprendizagem é um desafio a todos nós educadores que, até então, as temos exatamente sob a ótica das características do aprendiz. Suas condições orgânicas e psicossociais têm sido consideradas como os únicos obstáculos responsáveis pelo seu insucesso na escola (CARVALHO, 2000, p.60). 
Na perspectiva da escola inclusiva, é importante que a escola faça um planejamento com a finalidade de aproximar-se dos familiares, pois sua participação nas atividades escolares é de grande valor, afinal são eles que conhecem os filhos como ninguém. Sem dúvida que a evolução da educação inclusiva perpassa pela participação dos pais no processo de ensino aprendizagem de seus filhos. Sobre esse assunto, Machado (2009) faz referência a Mantoan:

A inclusão é uma inovação que implica um esforço de modernização e de reestruturação das condições atuais da maioria de nossas escolas, ao assumirem que as dificuldades de alunos não são apenas deles, mas resultam, em grande parte, do modo como o ensino é ministrado e de como a aprendizagem é concebida e avaliada (MANTOAN apud MACHADO, 2009, p. 98).

Na tentativa de obter melhores resultados de aprendizagem de todos os alunos, especialmente daqueles que necessitam de um atendimento especializado, é fundamental que a escola faça uma grande parceria com a família. A escola inclusiva deve estar atenta à necessidade de cada criança e planejar suas atividades, considerando as possibilidades de aprendizagem de seus alunos especiais com vista no coletivo, para que eles não se sintam excluídos do processo. Pamplin e Sigolo (2003) lembram que família da criança com necessidade educacional especial tende a tratar seu filho com mais dependência:

Nas famílias de crianças com necessidades educacionais especiais (NEE), as experiências vivenciadas num contexto podem perdurar por um período extenso das suas vidas, muitas vezes influenciadas pelo status de maior dependência infantil de seus cuidadores, apesar de terem a chance de participar de outros contextos de desenvolvimento de grande importância, como a escola (PAMPLIN \& SIGOLO, 2003, p.24). 
Com relação à criança especial, a escola pode deparar-se com uma família que protege seu filho por um período bem maior em comparação com as demais crianças, como foi colocado por Pamplin e Sigolo e essa proteção pode interferir no processo de desenvolvimento da criança, adiando as oportunidades de aprendizagem.

A nova escola fundamentada na inclusão anseia pela participação da família no espaço escolar por entender que ela necessite desse contato tanto quanto a escola. É na relação da família com a escola que a criança tem sua primeira experiência fora do meio familiar, tendo a oportunidade de interagir com outras pessoas.

Segundo o documento subsidiário à política de inclusão, algumas famílias de aluno com necessidade educacional especial posicionam-se contrárias ao processo de inclusão por não conhecerem as possibilidades da criança.

O Programa de Educação inclusiva faz alusão quanto à importância da família na escola:

Quando a família dispõe de meios efetivos de participação ativa e regular na vida da escola, gradativamente constrói a consciência de que a escola é um bem público que também é seu. Assim, geralmente desenvolve afetividade com relação à escola, assume maior responsabilidade com relação ao processo educacional de seus filhos e por conseqüência, passa a cuidar bem da escola. Além disso, a possibilidade de participar de programas educativos faz, dos familiares, membros efetivos da comunidade escolar (SEESP/MEC, 2004, p.18).

Quando a família observa que a equipe da direção, juntamente com os professores e os demais profissionais de educação, estão empenhados no desenvolvimento da criança e trabalham na perspectiva de atender às necessidades individuais de seus alunos especiais, conforme legislação vigente, ela tende a colaborar com a escola no processo de ensino aprendizagem de seu filho. 
O diálogo entre a família do aluno com deficiência e o professor é fundamental para o desenvolvimento da criança; as relações humanas acontecem porque as pessoas comunicam-se umas com as outras, por meio de palavras, gestos, olhares, contato corporal, entre outras formas de se expressar. As pessoas buscam o diálogo para se entenderem e fazerem-se compreendidas.

A partir do momento que a escola planeja suas atividades envolvendo a família, terá uma qualidade de ensino superior à das outras escolas que, por falta de planejamento, não conseguem trazer a família para participar do processo de ensino-aprendizagem de seu filho especial.

Para Paulo Freire (1987, p.19), "a primeira condição para que um ser possa assumir um ato comprometido está em ser capaz de agir e refletir". Deste modo, a política de inclusão no âmbito escolar requer o aparecimento de um novo ser que surge para modificar o cenário escolar, refletir sobre as questões da diversidade no processo de ensino aprendizagem dos alunos. Neste contexto, destaca-se o professor que media o aprendizado de seus alunos e promove a inserção destes no grupo, observando o comportamento de cada um e sensibilizando-os ao acolhimento de seus diferentes colegas.

É bom destacar um trecho da declaração de Salamanca que diz: " $A$ preparação adequada de todo pessoal da educação constitui um fator-chave na promoção do progresso em direção às escolas inclusivas" (Secretaria de Educação Especial / MEC, 2005).

Na perspectiva da escola inclusiva é importante ressaltar a importância da formação do professor para a aquisição de mais conhecimentos a respeito de seus alunos especiais. Os cursos de capacitação voltados para área de educação inclusiva contribuem para que os educadores revejam alguns conceitos, desmistificando possíveis preconceitos absorvidos por eles em suas experiências sociais. 


\section{II - OBJETIVOS}

\section{1- Objetivo Geral}

Compreender a importância do espaço escolar no cotidiano dos alunos com necessidade educacional especial, sob o ponto de vista deles, de seus familiares e de seus professores.

\section{2- Objetivos Específicos}

- Verificar a importância atribuída pelos alunos com NEE quanto ao seu espaço escolar;

- Identificar a participação de familiares de alunos com NEE no processo de inclusão escolar;

- Apontar quais são as dificuldades e avanços conquistados para o processo de inclusão escolar na perspectiva do aluno, da família e do professor. 


\section{III- METODOLOGIA}

\section{1- Fundamentação Metodológica}

Este trabalho está embasado nos pressupostos da pesquisa qualitativa, que segundo Martins e Bicudo (2005), buscam uma compreensão particular e sistêmica daquilo que estuda. A forma pela qual os dados são coletados na pesquisa qualitativa, a comunicação entre os sujeitos e o tratamento dos dados são feitos através da interpretação. $O$ foco de atenção da pesquisa qualitativa é centralizado no especifico, no peculiar, no individual, almejando sempre a compreensão do fenômeno em questão.

Segundo a pesquisa qualitativa, a investigação é um diálogo permanente em que as opiniões, cosmo visões, emoções e a subjetividade do sujeito estudado passam a ser elemento relevante para o curso do processo (MACIEL e RAPOSO, 2008). O pesquisador precisa se aproximar do fenômeno que está investigando para compreender a narração da experiência de mundo dos sujeitos que são seus objetos mais importantes da pesquisa (Martins e Bicudo, 2005). Para apreender toda essa complexidade do fenômeno, a pesquisa qualitativa exige instrumentos adequados que favoreçam a expressão espontânea dos participantes e a emergência de sua subjetividade.

De modo geral, a entrevista semiestruturada é um importante instrumento de diálogo entre o pesquisador e o entrevistado, em que as palavras são o meio principal de troca entre eles. Em outros termos, a entrevista qualitativa não é um processo unilateral em que as palavras passam de um (o pesquisador) para o outro (o entrevistado). Ao contrário, a entrevista é uma interação, um empreendimento social e cooperativo, no qual as várias e distintas realidades e seus significados são explorados, desenvolvidos e compreendidos. Isso significa dizer que ambos, entrevistado e pesquisador, estão envolvidos na produção do conhecimento sobre o fenômeno em investigação (BAUER e GASKELL, 2000). 


\section{2- Contexto de Pesquisa}

A escola onde a pesquisa foi realizada pertence à rede pública de ensino do Distrito Federal, localizada na cidade de Brasília. A instituição oferece Ensino Fundamental de nove anos (Séries Iniciais). No início da década de 90, iniciou-se $o$ atendimento aos alunos com deficiência mental e posteriormente aos alunos com deficiência visual.

Os alunos atendidos pertencem à comunidade local, mas há também alunos oriundos de outras cidades do Distrito Federal e do entorno. O número de alunos com necessidade especial é em torno de 50 alunos. Em virtude desse número significativo, há salas de recursos para o atendimento aos alunos com deficiência intelectual e com deficiência visual.

É perceptível a diversidade da escola, no sentido de atender aos variados públicos. Há alunos com necessidades educacionais especiais nas classes inclusivas e alunos-oriundos de diferentes classes sociais e etnias. Em função disso, a escola procura centrar o processo de ensino-aprendizagem nas diferenças de cada um, onde o desenvolvimento humano e suas inter-relações são ressaltados.

\section{3- Participantes da pesquisa}

A pesquisa contou ao todo com 11 participantes, sendo quatro professores atuantes na escola classe, em regência de turma, com classes inclusivas e Sala de Recursos. Estes professores têm mais de 37 anos, são casados, têm filhos e trabalham com educação inclusiva há mais de 8 anos. Participaram, também, três alunos com necessidades educacionais especiais que acompanham essas classes, sendo um deficiente visual e TDAH (Transtorno de Déficit de Atenção e Hiperatividade, um TDAH e um com Dislexia e DEPAC (Distúrbio no Processamento Auditivo Central). Ainda participaram da pesquisa, quatro mães de alunos com necessidade educacional especial. Segue abaixo um quadro caracterizando melhor os participantes. 
Quadro 1 - Participantes da pesquisa

\begin{tabular}{|c|c|c|c|c|}
\hline \multicolumn{5}{|c|}{ Professores participantes } \\
\hline Professores & Idade & $\begin{array}{c}\text { Tempo de } \\
\text { magistério }\end{array}$ & $\begin{array}{c}\text { Atendimento } \\
\text { aos ANEEs }\end{array}$ & Formação \\
\hline Prof. A & 38 anos & 16 anos & 16 anos & Pedagogia \\
\hline Prof. B & 37 anos & 17 anos & 8 anos & Pedagogia \\
\hline Prof. C & 45 anos & 21 anos & 13 anos & Educação Inclusiva \\
\hline Prof. D & 47 anos & 26 anos & 10 anos & Pedagogia/Artes \\
\hline \multicolumn{5}{|c|}{ Alunos participantes } \\
\hline Alunos & Idade & Diagnóstico & Ano \\
\hline Aluno A & 13 anos & DV e TDAH & $2^{\circ}$ ano \\
\hline Aluno B & 10 anos & TDAH \\
\hline Aluno C & 12 anos & DISLEXIA E DEPAC & $5^{\circ}$ ano \\
\hline \multicolumn{5}{|c|}{ Familiares participantes } \\
\hline Família & Idade & Quantidade de filhos & Profissão \\
\hline Mãe A & 42 anos & \multicolumn{2}{|c|}{04} & Dona de casa \\
\hline Mãe B & 40 anos & 02 & Dona de casa \\
\hline Mãe C & 35 anos & 03 & Dona de casa \\
\hline Mãe D & 51 anos & 02 \\
\hline
\end{tabular}

Em coerência com a pesquisa qualitativa, a própria pesquisadora colocase na condição de participante por: atuar como professora de Geografia em uma escola inclusiva; por estar envolvida com o tema; e por ser mãe de um menino com síndrome de Down, conforme descrito na apresentação deste trabalho.

\section{4- Materiais e Instrumentos utilizados}

Os materiais de pesquisa utilizados foram um gravador digital, caneta e papel para registrar os pontos principais. Como instrumento, foi utilizada a 
entrevista semiestruturada, que fora composta por três roteiros, contendo perguntas direcionadas aos três grupos distintos de participantes: primeiro roteiro teve por objetivo reconhecer as diversas atitudes adotadas pelos professores ao receber o aluno com necessidade educacional especial; 0 segundo roteiro foi desenvolvido para os ANEEs, cujo objetivo era apreender os significados que eles atribuem ao espaço escolar; e o terceiro roteiro, aplicado aos familiares, objetivou conhecer quais as expectativas da inclusão escolar e a importância do espaço escolar na vida dos envolvidos.

Para complementar as informações da entrevista, ainda foi utilizada a observação, realizada no ambiente escolar a fim de saber como ocorre a interação dos ANEEs com todo o grupo no cotidiano da escola e a importância de tal convívio nesse espaço. Os roteiros correspondentes encontram-se nos apêndices $A, B, C$ e D.

\section{5- Procedimentos de Construção de Dados}

Inicialmente foi feito o contato com a direção da escola por meio de uma Carta de Apresentação, fornecida pela Universidade Aberta do Brasil em parceira com a Universidade de Brasília (ver anexo A), na qual continha os objetivos da pesquisa e o compromisso com as questões éticas por parte da pesquisadora. Após esse consentimento, procedeu, o convite aos professores, aos familiares dos ANEEs e aos próprios ANEEs. Foi apresentado o Termo de Consentimento Livre e Esclarecido aos participantes que, após anuírem, responderam ao instrumento de pesquisa (ver anexo B). Cumpre lembrar que para os participantes ANEEs a autorização e assinatura do Termo foram dadas pelo seu responsável.

As entrevistas foram agendadas por uma professora da sala de recursos, conhecida comum da pesquisadora e dos demais participantes da pesquisa e por isso, teve importante mediação entre esses diferentes interlocutores.

As entrevistas aconteceram no espaço da escola e foram realizadas no mês de dezembro de 2010. Todas as entrevistas foram gravadas e transcritas na íntegra (conforme anexo) para facilitar a análise dos dados. 
Posteriormente, foi feito a observação com o intuito de levantar algumas informações sobre as interações sociais no âmbito da escola, dando ênfase na relação dos ANEEs com os demais, na perspectiva de inferir questões sobre a inclusão, com vistas a aprimorar o conhecimento sobre o assunto aqui apresentado.

\section{6- Procedimento de Análise de Dados}

É importante ressaltar que as entrevistas aconteceram de uma maneira natural, onde os entrevistados apresentaram-se tranqüilos, demonstrando confiança e interesse ao tema abordado.

Após a transcrição das entrevistas, a pesquisadora analisou cuidadosamente as falas de todos os participantes. Em uma primeira leitura, buscou-se verificar os significados que os participantes construíram em torno do tema da pergunta. Em uma segunda leitura, tais significados foram bem mais compreendidos em relação a toda a entrevista do participante. A terceira leitura foi realizada com o objetivo de fazer as inter-relações entre a fala do participante nos seus diferentes momentos da entrevista com as falas dos demais entrevistados.

A partir das falas, emergiram quatro categorias amplas, a saber: 1 - A inclusão escolar e o encontro das leis; 2 - O espaço escolar como promotor de desenvolvimento para o aluno especial; 3 - Família: a presença da mãe na escola; 4 - As dificuldades e os avanços no processo de inclusão escolar. Tais categorias foram analisadas à luz da teoria adotada, conforme apresentação no capítulo a seguir. 


\section{IV-RESULTADOS E DISCUSSÃO}

Para efeito de apresentação deste capítulo, pretende-se destacar as falas dos participantes que foram mais significativas e reveladoras das categorias de análises. Para maior compreensão sobre o fenômeno estudado, as falas dos distintos participantes e as demais informações apreendidas, a partir da interação pesquisador/pesquisado, estão dispostas de forma entrelaçadas e analisadas concomitantemente ao referencial teórico adotado.

\section{1- Categoria 1 - A inclusão escolar e o encontro das leis}

Sabemos que a legislação é um importante instrumento social que depende, para sua efetivação, de quem a aplica e para quem se aplica. A partir desse pressuposto, nesta categoria pretendemos abordar a inclusão escolar e a legislação vigente sobre tal temática, partindo das falas das professoras participantes da pesquisa. Reflexões sobre a função do Estado, a efetividade e respeito às leis, entre outras ideias são pautas de análise neste momento.

Quanto às questões próprias à legislação, as professoras entrevistadas colocaram-se bastante preocupadas. A professora diz:

Eu acho que tem que ter investimento na inclusão. É um direito dessas crianças, agora também cabem a nós, professores da sala de recursos, conscientizar os pais desses alunos, eu acho que eles tem muito mais poder do que eles pensam, logo que eles corre atrás eles conseguem as coisas mais do que nós professores. O Estado só faz quando ele é cobrado ( $\left.\operatorname{Prof}^{a} D\right)$.

A inquietação da professora encontra respaldo nas afirmações de Carvalho (2003, p. 16) quando esta diz que "as violações de direitos são, sem dúvida, um dos mais significativos entraves à democracia e a paz". A democracia representa 0 direito de todos de participar ativamente como cidadão e para que haja democracia de fato, todas as pessoas devem usufruir dos direitos conquistados por meio da legislação. A professora $\mathrm{C}$ coloca que: 
A inclusão ainda está em processo, à inclusão é uma coisa muito mais ampla, a gente precisa de políticas públicas, uma coisa muito batida, muito falada, mas a gente precisa de política pública voltada pra inclusão, a gente precisa também de mais esclarecimentos, mais incentivos, mais conhecimentos (Prof ${ }^{a} \mathrm{C}$ ).

A professora $C$ faz alusão às políticas públicas e diz que apesar de serem muito discutidas, ainda há uma lacuna a ser preenchida. A professora $B$ desabafa:

A secretaria precisa tratar a inclusão com seriedade, as escolas precisam estar preparadas, só as salas de recursos não tão dando conta do recado, não por uma questão de incompetência, mas por uma questão da demanda. Tem uma série de coisas que tem que acontecer para a inclusão realmente acontecer como se prever no papel e acontecer como é o ideal de todo mundo, de uma forma que todos ganhem, no momento eu acho que o ganho é muito pequeno e tem muito mais prejuízo (Prof ${ }^{a} B$ ).

A professora B questiona a necessidade das escolas se prepararem para que a inclusão aconteça de fato e de direito. Para Machado (2009, p.11) "a educação especial não se esgota na evolução de seu entendimento legal, mas deve afetar diretamente a vida escolar, como proposta de ação educativa".

Concluindo as falas das professoras sobre o tema de legislação, a professora enfatizou: "Tudo que tá no papel tem que sair e vir para a prática que a lei no papel é fantástica! Eles são amparados em tudo, mas só que na prática a gente ver que isso não acontece" (Profa $A$ ).

Todos os participantes foram categóricos ao afirmar que as leis não são respeitadas, permanecendo lindas no papel, mas sem efeito prático. Embora as leis existam, as professoras questionam a escassez de investimento voltado para a educação inclusiva, a falta de política pública, a pouca participação dos pais dos alunos com deficiência que precisam mobilizar-se e cobrar mais do Estado. Uma das participantes diz que os pais têm muito mais autoridade para 
cobrar do que eles imaginam. Isso implica que não bastam as leis, é preciso que haja cobrança para saírem do papel e fazer valer os direitos de inclusão escolar.

Com vista na educação inclusiva, é fundamental que todos encontrem novos caminhos para atender aos alunos com necessidade educacional especial, tendo como base a Declaração de Salamanca (1994): O Princípio da Inclusão consiste no reconhecimento da necessidade de se caminhar rumo à "escola para Todos" - um lugar que inclua todos os alunos, um lugar que celebre a diferença, que apóie a aprendizagem e responda às necessidades individuais, na tentativa de conquistar uma educação com qualidade. Nesse sentido, Simão diz que ainda há um longo caminho a ser percorrido para a garantia do direito à educação (2010).

As leis existem, conforme foi colocado em uma das partes desta pesquisa, mas isso não significa que a inclusão escolar está garantida para todos os alunos com deficiência. Há um percurso longo que devemos fazer para garantir a inserção de todos os alunos com necessidade educacional especial no processo de ensino aprendizagem, conforme foi colocado pelas professoras aqui entrevistadas.

"As leis que garantem a inclusão já existem a tempo suficiente para que as escolas tenham capacitado professores e adaptado a estrutura física e a proposta pedagógica" (CAVALCANTE, p.14). Essas leis permitiram um salto qualitativo na educação e na formação do professor na preparação para a escola inclusiva, no entanto para que as leis sejam exercidas, é necessário que a sociedade exija o cumprimento delas.

Conforme foi discutido nessa categoria, para que haja uma inclusão escolar nos moldes da lei e baseada nos direitos humanos, é imprescindível que a escola trace metas, que convide a comunidade a participar ativamente com o objetivo principal de trazer para este ambiente, a permanência de todos os alunos.

\section{2- Categoria 2 - 0 espaço escolar como promotor de desenvolvimento para o aluno especial}


A aprendizagem do aluno especial está diretamente relacionada ao conhecimento do professor sobre a questão da inclusão e ao diálogo que é construído com a família, especialmente com a mãe, que na grande maioria das vezes, é quem acompanha o filho e está presente na vida escolar dele, como foi constatado na escola aqui pesquisada. Depois das observações feitas na esfera escolar e das análises das entrevistas, nesta categoria esperamos discutir e relacionar o espaço da escola como o agente de mudanças na vida do aluno, sobretudo no que se refere à interação social e a oportunidade de desenvolvimento no processo de ensino-aprendizagem do aluno com NEE e a importância da formação do professor no que concerne a inclusão escolar.

Iniciamos com o tema sobre a importância do espaço escolar pensando no desenvolvimento do aluno com NEE. A professora salientou:

O espaço tem que ser visto como primordial, a sala de aula e a escola não podem ter obstáculos, precisa atentar para sinalizadores no chão. É fundamental que o deficiente visual possa se locomover dentro desse espaço, para que a inclusão ocorra realmente, ele tem que ter acesso as coisas, tem que se sentir independente nesse espaço que é importante para o desenvolvimento das crianças (Prof ${ }^{a} A$ ).

A professora ressalta a importância da adaptação dos espaços da sala de aula e da escola para que alunos com deficiência visual possam percorrer seguros, com a finalidade de atender as suas necessidades. A respeito desse tema Raposo e Carvalho ponderam: "A locomoção com independência e autonomia e a participação efetiva em todos os espaços exige adaptações que minimizam as barreiras arquitetônicas, urbanísticas e de mobiliário". (Raposo \& Carvalho, 2005, p. 9).

Para a professora "B" "O espaço escolar é fundamental para o desenvolvimento dos alunos porque é rico em estímulos, em oportunidades para que as crianças especiais se desenvolvam em todas as áreas de aprendizagem". "O espaço escolar é importantíssimo porque aqui o aluno vai fazer suas relações sociais, eles começam a ter mais seguranças no relacionamento com as outras pessoas". (Prof ${ }^{a} A$ ). 
Para Vigotsky "a intervenção deliberada dos membros mais maduros da cultura no aprendizado das crianças é essencial ao seu processo de desenvolvimento" (OLIVEIRA, 1993, p.105) Partindo desse pensamento, destacamos o professor como aquele que exerce uma função primordial na vida dos alunos, contribuindo para que eles desenvolvam suas potencialidades na escola que é um espaço onde as crianças ocupam desde muito cedo.

A prof" $\mathrm{C}$ diz que "é no espaço escolar que o aluno aprende troca experiências, ali vai ser oportunizada várias oficinas, experiências novas com crianças diferentes, com professoras diferentes, conteúdos, habilidades diferentes". Na perspectiva das professoras, o espaço escolar modifica a vida do aluno com NEE porque promove a aprendizagem e a interação social, contudo sabemos que a inclusão é muito complexa, devido às diversas realidades encontradas e consequentemente requer mudanças em todos os segmentos sociais. Simão (2010) aborda esse tema de modo objetivo:

Para a inclusão escolar ter sucesso e para a educação especial ter espaço, precisa sair da reflexão e partir para a ação, sair da teoria e passar a pratica, ampliando os conhecimentos com calma e seriedade, pois as mudanças não serão num piscar de olhos e as dificuldades não estão somente na questão da inclusão (SIMÃO, 2010, p.15).

A sociedade enfrenta uma série de desigualdades em todas as áreas da vida humana, mesmo considerando os intensos debates sobre a importância da inclusão e da sensibilização de todos a respeito do tema de maneira especial. A inclusão escolar, objeto de nosso estudo está distante de ser alcançada, pois precisamos lutar também por uma sociedade ideal.

Quanto às entrevistas dos alunos especiais, eles exteriorizam um sentimento bom pela escola, dizendo que a mesma traz oportunidade de aprendizagem e de interação com o outro. $\mathrm{E}$ o que eles mais gostam de fazer na escola é de estudar e também de brincar com os colegas na hora do recreio. (Anexo $\mathrm{C}$ ). As falas dos alunos confirmam a importância deles estarem ocupando o espaço da escola, numa expectativa de aprender com o outro. Tunes, Tacca e Martinez (p.109), fazem referência ao conceito de zona de 
desenvolvimento proximal de Vigotsky dizendo que o caráter social da aprendizagem escolar expressa-se também no papel do Outro nesse processo, um Outro que intencionalmente se propõe, a ensinar.

De acordo com Oliveira (1993, p.105) destaca-se nas postulações de Vigotsky a importância da atuação dos outros membros do grupo social na mediação entre a cultura e o indivíduo e na promoção dos processos interpsicológicos que serão posteriormente internalizados.

Quando questionados sobre o que fazem no horário do recreio, responderam: "Eu fico jogando jogo de carta baralho com os meus amigos", outro disse: "Brinco de policia e ladrão, brinco de várias coisas", e o terceiro falou: "Eu brinco, eu converso. É hora que eu tenho pra brincar com meus amigos e me diverti" (Anexo C). O aluno $\mathrm{E}$ disse que na hora do recreio conversa com os colegas que estão brigando e colocou: "Quando um briga eu digo não pode, não pode ser assim!".

Para Nogueira (1995, p.16) desde os primeiros momentos de vida da criança, o desenvolvimento das funções psicológicas superiores é sempre mediado pelo outro que aponta, atribui e/ou restringe os processos de significação da realidade.

Quanto à importância de vir para a escola, os participantes disseram: "a gente aprende mais a ler e escrever do que ficar naqueles negócios de criminalidade, aquelas coisas". (Aluno A); "pra gente ter um aprendizado bom. É aprende, é brincar". (Aluno C); "pra mim crescer e ter um bom emprego, ter um emprego no futuro. Ter um emprego garantido". (Aluno B).

Todos os alunos entrevistados disseram que é bom estudar na escola, que gostam da hora do recreio porque brincam com os colegas, que seu professor facilita a participação deles na aula e quando necessitam de alguma ajuda, solicitam ao professor.

Finalizando o tópico sobre o espaço escolar como agente do desenvolvimento dos alunos com necessidade educacional especial, abordamos a seguir o relato das mães entrevistadas.

Quando fora perguntado para a mãe B o que a escola representa para seu filho com NEE ela respondeu: 'Representa muito na vida dele, sem a escola eu nem sabia como seria a vida dele, seria muito difícil'. Ela disse que a coisa melhor para seu filho é ir para a escola, que ele nunca mata um dia de 
aula e o que ele mais gosta é de estudar, mesmo aprendendo muito pouco. Ela complementou: "As professoras dele cada uma é mais maravilhosa que a outra e isso é muito importante". Sobre o espaço escolar Carvalho coloca com propriedade:

Também faz parte do espaço escolar uma outra dimensão, e que inclui as atitudes daqueles que transitam, cotidianamente, no interior da escola. Este espaço atitudinal é difícil de ser quantificado, pois envolve elementos não mensuráveis tais como conhecimentos, as experiência, os sentimentos, filosofia de educação daqueles que convivem, permanentemente, no intramuros das escolas. (CARVALHO, 2003, p.179).

Para a mãe $A$, a escola representa o desenvolvimento social e ela espera que seu filho seja alfabetizado, que aprenda a ler e escrever. Ela diz que as professoras são boas e que o processo de aprendizagem de seu filho é devagar mesmo. A mãe C diz: "A escola é muito importante na vida do meu filho. Ela dá todo o apoio que ele precisa para que ele cresça cada vez mais". Por último a mãe nos coloca que a escola:

Representa um momento de interação, de socialização ele se sente muito feliz, mesmo quando ele está febril ele pede remédio e diz que não pode faltar. Então isso me mostra que pra ele isso muito importante que ele gosta muito, ele já cresceu muito na escola já amadureceu já se socializou demais (Mãe D).

É perceptível que para as mães a escola ocupa um lugar primordial na vida de seus filhos especiais. Algumas não conseguem sequer imaginar o que seria de seus filhos sem a escola. Segundo as mães aqui entrevistadas, o espaço da escola representa para seus filhos um lugar que promove a interação, a aprendizagem, e que eles se sentem valorizados, acolhidos e realizados. Notamos que as mães estão muito satisfeitas com o processo de inclusão na escola por meio da alegria expressa pelos seus filhos em relação à mesma. 
A partir do momento em que a escola demonstra interesse pelo aluno especial, incentivando-o a desenvolver-se como cidadão e evidenciando o potencial de aprendizagem de cada um é notório que os laços da família com a escola estreitem-se, tema que trataremos na categoria a seguir.

\section{3- Categoria 3 - A família: a presença da mãe na escola}

Os alunos entrevistados disseram que vêm para a escola com a sua mãe. A presença da mãe na escola é marcante, na grande maioria dos casos, são as mães que acompanham seus filhos com necessidade educacional especial. Muitas, por morarem distantes, aguardam seus filhos na própria escola no período em que eles estão estudando. Nesta perspectiva, esperamos abordar nesta categoria a atuação incessante da mãe para conquistar um espaço para que seu filho especial seja inserido na sociedade por meio da escola.

Apresentaremos as falas das mães no tópico sobre a relação família com a escola e de que forma esta promove a participação dela no processo de aprendizagem de seu filho especial. As respostas das mães foram bem parecidas: "A escola interage com os pais, tem um vínculo muito grande com os pais, então ajuda muito na aprendizagem dele". (Mãe C). "A escola promove reuniões periódicas, coloca à disposição dos pais o material utilizado, 0 relatório do aluno em todas as áreas de estudo". (Mãe D). A mãe B disse que a escola foi crucial porque seu filho não conseguia aprender e por orientação da professora ela procurou o neurologista e a partir do diagnóstico do médico ela descobriu o que ele tinha e agora ela está admirada com seu desenvolvimento.

Pelos relatos colhidos das mães participantes a escola tem uma boa comunicação com a família, seja por meio de reuniões, por exposições de materiais e principalmente pelo diálogo construído nesta interação. É de fundamental importância que todas as escolas enfatizem a colaboração entre 0 lar e a escola. Pacheco (2008).

Na perspectiva da participação da família é preciso que haja consciência social tanto da parte dos educadores que atuam no interior da escola, quanto da comunidade que no seio da sociedade civil, preocupa-se e valoriza a 
mesma. "O espaço escolar é, pois, um espaço privilegiado para construir e capilarizar uma cultura de participação, de autonomia, de cidadania, de planejamento participativo como instrumento de transformação social". (SE$\mathrm{RS})$.

É evidente que no processo de inclusão escolar a família enfrenta muitas dificuldades com um objetivo único de oportunizar o seu filho especial a ocupar um espaço digno no meio em que vive. Continuando sobre o tema da participação da família na escola, relatam os professores:

A família conhece muito mais o aluno, a criança quando vem de casa vem de outra escola esse histórico pra nós de sala de recursos é muito importante então essa interação é feita em primeira mão pela família, sala de recursos e professora também e essa troca toda ajuda no processo de ensino aprendizagem da criança melhora o crescimento da criança vem muito mais forte quando todos ali participam (Prof ${ }^{\text {a }}$.C).

Faz-se necessário que o professor valorize o conhecimento e as experiências que o aluno traz da família para a escola. Para Chraim (2009, p.26) "É na base familiar que a criança começa a construir sua real identidade, que será formada a partir das experiências e da forma como aprendeu a lidar com as informações que recebe".

A professora destacou a importância da presença dos pais na vida escolar de seus alunos, com destaque para o aluno especial. "Os pais presentes a gente sabe que os filhos deles são bem mais motivados, porque sabem que tem alguém que vai cobrar que vai olhar que vai perguntar que tem interesse. Com certeza ajuda muito. (Prof ${ }^{\mathrm{a}}$ A). Quando a família participa do processo de ensino aprendizagem de seu filho, a possibilidade de crescimento torna-se maior. A professora disse que sempre solicita aos pais acompanharem seus filhos na tarefa escolar:

Quando eu preciso de ajuda eu peço, olha! Tá indo o dever de casa! Precisa ler mais! Não deixa ficar a toa põe pra estudar em casa. Eles me ouvem muito e me ajudam muito também, 
participam bastante, principalmente no início quando eu peguei a turma, hoje já tá mais tranqüilo. (Profa ${ }^{a}$ ).

As professoras apontam a importância da participação da família no processo de ensino aprendizagem do filho com necessidade educacional especial e o quanto os alunos desenvolvem quando a família acompanha e está envolvida no processo de ensino aprendizagem de seu filho.

\section{4- Categoria 4 - As dificuldades e os avanços no processo de inclusão escolar}

Quanto ao processo de inclusão escolar é importante salientar que apesar das muitas dificuldades enfrentadas pelos alunos, pelas famílias e pelos professores, os avanços estão acontecendo de maneira contínua e gradual. Sobre esse tema iremos discorrer nesta categoria, onde serão consideradas as falas dos pais, dos alunos e dos professores.

Ao perguntarmos quais as maiores dificuldades encontradas no processo de inclusão escolar de seu filho a mãe questionou: "A Inclusão não é os deficientes interagir com os outros alunos como todos fossem iguais? Mas na verdade ainda tem preconceito por parte dos outros alunos". A mãe evidenciou o preconceito e a falta de interação com os outros como fatores que dificultam a inclusão escolar. A mãe desabafa:

"Que a turma é grande que tem 29 alunos, sendo que 3 com deficiência e cada um com a sua dificuldade, teria de ter um monitor para quando a professora estiver passando matéria, o monitor estaria fazendo uma adequação com os alunos especiais e mesmo assim a adequação de cada um é diferente porque o aluno especial também é diferente um do outro". (Mãe A).

De acordo com as mães entrevistadas o processo de inclusão apresenta alguns problemas os quais não deveria existir e que o grande número de alunos na sala inclusiva interfere na aprendizagem de seus filhos 
especiais; deste modo o professor não consegue dar um atendimento individual aos seus alunos, principalmente aos especiais e se fazendo necessária a presença de um monitor para solucionar parte dos problemas. Para que 0 sistema educativo se reformule, há necessidade de mudar a atitude dos educadores frente à diferença, bem como todo um conhecimento de como facilitar a experiência de aprendizagem a alguns alunos. (Carvalho, 2003, p.151).

Ao serem entrevistadas, as professoras listaram algumas dificuldades enfrentadas por elas no processo de inclusão: Para a professora $C$ a dificuldade que ela considera bem marcante é "o rótulo de incapacidade, isso de forma geral as pessoas vêem as crianças com Síndrome de Down com um olhinho puxado aquele ali é deficiente não sabe de nada". Para a professora D a maior dificuldade enfrentada por ela "foi à falta de recursos materiais, no início era utilizado a máquina Braille que é muito pesada para fazer todo material e que a ampliação era feita à mão, já que não tinha computador".

Sobre os avanços conquistados ao longo do processo, as professoras disseram que a aceitação é um ponto positivo porque o tema está mais divulgado e fica mais fácil lidar com a inclusão. A escola está toda envolvida, do porteiro ao gestor e que a inclusão acontece. Uma das professoras nos disse: "Eu vejo os avanços das crianças com elas mesmas, elas acabam crescendo com o convívio com as outras".

Enquanto as professoras consideraram a aceitação por parte dos profissionais de educação positiva, uma mãe destacou que uma das dificuldades é a falta de aceitação por parte de alguns alunos em relação à criança especial, confirmando o preconceito existente.

Ao perguntarmos para as mães quais foram os avanços conquistados no processo de inclusão de seu filho, uma das entrevistadas falou:

Os avanços foram muitos hoje meu filho é outra pessoa, ele hoje conversa, tem um vocabulário grande, domina o computador, não pela escola porque lá ele quase não usou o computador, acho que nem usou, mas em casa devido essa interação e socialização a auto estima dele subiu muito então ele aprende com mais facilidade, domina, baixa sites, entra 
em sites, baixa jogos, enfim joga, navega na internet acompanha programa de TV, acompanha campeonato de futebol, de automobilismo pela internet, imprime lista, enfim hoje eu sinto ele muito mais feliz com essa escola, pra ele foi muito importante. (Mãe D).

Continuando sobre os avanços que aconteceram no processo de inclusão da vida de seus filhos, uma mãe disse:

Melhorou bastante, quando meu filho entrou na escola tinha professor que nem sabia o que era Síndrome de Down, ele teve que correr atrás, procurar porque na época a fundação não dava curso hoje em dia tá assim tem muito curso para professor, antigamente não tinha então ás vezes o professor tinha que correr atrás. É um avanço! Tem que avançar mais. Mas já deu um a melhorada. (Mãe A).

Duas mães disseram que seus filhos não aprendiam a ler e a escrever e que foi neste ano que eles foram alfabetizados. Estão lendo e escrevendo e para elas, isso foi o grande avanço no processo de inclusão de seus filhos. As duas mostraram-se deslumbradas quanto ao desenvolvimento dos mesmos em tão pouco tempo. (Anexo C).

É importante ressalvar que quanto mais investimentos na área de educação voltada para a inclusão escolar, mais oportunidades terão os alunos com NEEs de desenvolver seus potenciais. A aceitação e o respeito da inserção do aluno especial na escola podem trazer um novo enfoque ao processo de inclusão. Para obter bons resultados no processo de ensinoaprendizagem, o professor deve observar seus alunos com a finalidade de conhecê-los melhor.

Muitas vezes a falta de conhecimento sobre o assunto, acompanhada pelo preconceito enraizado na sociedade é que nos distancia do contato com o outro, com o diferente. Deste modo, a formação dos profissionais da educação é de fundamental importância para a melhoria do processo do ensino, especialmente, o conhecimento voltado para a educação inclusiva. As informações devem estar pautadas na reflexão que conduz a pensar qual é a 
fala que se produz na prática, com finalidade de transformar o conhecimento adquirido na ação pedagógica.

Cada aluno é diferente um do outro, compete ao professor estimular a habilidade de seus alunos, na perspectiva de promover o desenvolvimento e a aprendizagem. Todas as questões relacionadas à educação são amplas até mesmo quando é oferecido curso de capacitação aos professores. Sobre esse assunto o Documento subsidiário à Política de Inclusão ressalta que:

Umas das dificuldades encontradas na formação dos educadores, no estudo de alguns fundamentos teóricos para o trabalho com alunos com necessidades educacionais especiais, é o amplo leque de realidades sócio-culturais existentes em nosso país. Para atender esta demanda tão diversa, o material dirigido à formação tem se proposto oferecer uma linguagem suficientemente abrangente para ser acessível a todos. Porém, em alguns casos, se observa a excessiva simplificação dos conteúdos propostos, aliada a uma superficialidade que se distancia das situações problemáticas concretas de cada realidade (Secretaria de Educação Especial /MEC, 2005, p.21).

O estudo realizado no próprio órgão do governo adverte que uma das dificuldades encontradas na organização da capacitação dos professores é a diversidade das realidades sócio-culturais do nosso país. Apesar das dificuldades na aplicação dos cursos de formação dos educadores é imprescindível a continuidade destes no que concerne a educação inclusiva.

É sabido que a sociedade está sempre em transformação, deste modo na escola, as mudanças acontecem constantemente e a inclusão faz parte de um novo modelo social que garante a todos os alunos a sua permanência. Quanto à vinda de aluno com NEE na escola a professora diz:

Hoje em dia eu acho que é mais fácil de todo mundo aceitar a questão do aluno com necessidade especial porque já está mais divulgado, já se fala mais nisso porque antigamente 0 professor vinha para a escola quando tinha um aluno na sala 
com deficiência ele escolhia e não ficava naquela sala. Ele podia escolher. Hoje nem isso pode mais e eu acho certo isso. Você tem que gostar. Não sabe? Vai atrás. Realmente falta curso de capacitação o professor também hoje tem que ir atrás de algumas coisas. (Prof $\left.{ }^{\mathrm{a}} \mathrm{A}\right)$.

A fala da professora demonstra que a partir das mudanças acontecidas na sociedade, os professores tendem mudar suas posturas e se interessam por assuntos que até então desconheciam, como o tema inclusão. Enquanto outra professora diz:

Eu acho que a secretaria tinha que investir mais na qualificação dos profissionais. Eu acho que a inclusão dos alunos especiais ela é uma questão muito séria e a secretaria não dá devida seriedade. $O$ professor tem de ter perfil para trabalhar com o ensino especial, não é todo professor que tem perfil, às vezes até tem o conhecimento, mas não tem o perfil e tem outra, são muitas áreas, então tem o Down, tem o que é Cadeirante, tem o Deficiente Visual, tem o que é Condutas Típicas, sabe e o professor da sala regular ele já tem que dá conta de muitos alunos e ainda se especializar em alguma deficiência, alguma área específica. (Prof $\left.{ }^{\mathrm{a}} \mathrm{B}\right)$.

Após relato das falas das professoras $A$ e $B$, percebe-se que ambas falam da importância da formação do professor por meio de cursos de capacitação para aquisição de conhecimentos a respeito da educação inclusiva. A professora $A$ entende que o professor tem que buscar conhecimento para atender os alunos especiais, enquanto a professora B acha que não adianta ter muito conhecimento, o professor tem de ter perfil para atender os alunos especiais.

Por meio dos cursos de formação direcionados à educação inclusiva, o professor terá mais oportunidades de obter conhecimentos sobre seu aluno especial, contribuindo para que o processo de ensino aprendizagem pautado na diversidade, no respeito, na compreensão, sobretudo no direito garantido por lei, que oportuniza a todos o acesso ao conhecimento, independente de 
sua cor, credo, raça, entre outros, tendo em vista às possibilidades de cada um desenvolver-se dentro de um grupo, com a finalidade de que todos alcancem níveis de aprendizagem que superem as suas expectativas.

A partir daí, o professor poderá trazer um novo olhar para as mudanças que estão acontecendo e que deverão intensificar-se nos próximos anos, que é a inclusão dos alunos especiais nas escolas regulares.

A adequação curricular pode também contribuir no avanço do processo de ensino-aprendizagem do aluno, as adaptações serão utilizadas com 0 objetivo de diminuir as barreiras que existem entre vários níveis sociais. "O currículo é um referencial de base nacional, conforme determinam os artigos 26, 27 e 32 da LDBEN, e deve ser desenvolvido levando em consideração os aspectos culturais locais e as peculiaridades dos educandos" (Secretaria de Educação Especial / MEC, 2005, p. 27).

Adequação curricular não significa atividades mais fáceis é 0 reconhecimento que cada um aprende de maneira e ritmo próprio, baseado na política da inclusão. Para promover a aprendizagem do aluno independentemente se ele é especial ou não, o professor deve selecionar o currículo voltado para cada turma e especificamente para o aluno individual, respeitando o ritmo de aprendizagem de cada um.

Para que haja inclusão escolar de fato é imprescindível que os profissionais envolvidos diretamente com a educação tenham uma visão favorável a respeito da importância da convivência humana, baseada na diversidade. O Ministério da Educação, juntamente com a Secretaria de Educação Especial coloca que:

A inclusão é percebida como um processo de ampliação da circulação social que produza uma aproximação dos seus diversos protagonistas, convocando-os à construção cotidiana de uma sociedade que ofereça oportunidades várias a todos os seus cidadãos e possibilidades criativas a todas as suas diferenças (MEC/SEE, 2005, p.34).

A inclusão escolar necessita permanentemente de professores comprometidos com o aluno com NEE, de professores que se atualizem sobre 
o tema de inclusão, que busquem mais informação sobre o assunto, "um dos fatores mais importantes para o sucesso da inclusão de um estudante com NEE, diz respeito à interação deste com o professor" (GOMES \& BARBOSA,).

Após as análises das categorias percebemos o quanto é importante a inclusão no espaço da escola para os alunos com necessidade educacional especial, para a sua família e também para todos os que ocupam esse espaço. A escola é promotora do desenvolvimento de aprendizagem de seus alunos e também possibilita uma maior interação, respeitando as individualidades e ressaltando a importância de viver socialmente.

Apesar das dificuldades, os avanços estão acontecendo e é perceptível que a legislação tenha contribuído para que a inclusão escolar aconteça, podendo alcançar níveis cada vez maiores. Cabe a todos nós envolvidos nesse processo continuarmos a discussão e principalmente cobrar políticas públicas cada vez mais direcionadas, para que a inclusão de nossos alunos aconteça de fato e de direito no espaço escolar. 


\section{V- CONSIDERAÇÕES FINAIS}

Este trabalho teve por objetivo compreender a importância do espaço escolar para os alunos com necessidade educacional especial, enfatizando a participação de suas famílias, as dificuldades e os avanços conquistados para o processo de inclusão.

De acordo com os dados da pesquisa, as famílias depositam uma grande esperança na escola, os alunos estão satisfeitos e os professores buscam por meio do conhecimento diminuir as diferenças encontradas em suas turmas, oportunizando a todos os meios de aprendizagem. As dificuldades da inclusão escolar são postas nas falas das mães e das professoras no decorrer desse estudo como os avanços conquistados nesse processo.

As leis representam um ponto de partida para a efetivação da inclusão, as pessoas que cobram junto ao Estado o direito de todos os cidadãos de serem inseridos na sociedade são respaldadas pela legislação. As leis que garantem à inclusão dos alunos com necessidades especiais na escola trazem também a necessidade de oferecer aos professores cursos de formação numa perspectiva de promover o conhecimento na área de educação inclusiva, como foi visto neste trabalho.

Respeitar a diversidade humana não é tarefa muito fácil porque temos que rever firmemente a nossa postura perante tantas desigualdades e preconceitos dos quais nos deparamos constantemente. Diante de tanta adversidade resta-nos sensibilizar e juntarmos às outras pessoas que lutam por uma sociedade mais justa, onde todos possam participar da vida social e terem acesso ao conhecimento.

Para Correr (2003, p.33) "O desafio de garantir o direito à participação de todas as pessoas na sociedade é integrado ao desafio de o fazer com garantia também de qualidade de vida". Na perspectiva de inclusão social é importante discutir a inclusão escolar que pode ser um ponto de partida para o processo de inclusão no âmbito de outros contextos sociais. Portanto, é bom lembrar que todos devem ter oportunidades de aprender, independente de 
suas condições e toda aprendizagem é fundamentada nas possibilidades de cada um.

O espaço escolar exerce um papel importante que possibilita a interação social dos alunos com necessidades educacionais especiais com os demais, conforme constatamos no decorrer de toda a pesquisa e ao entrevistar os alunos especiais, suas mães e suas professoras.

Ainda que encontremos, no espaço escolar, algumas contradições, este representa para a família dos alunos especiais uma possibilidade a mais de inclusão e principalmente para os alunos especiais que se sentem satisfeitos frequentando a escola e inseridos no contexto social de sua comunidade, segundo as falas dos entrevistados.

De acordo com o censo de 2000 a população brasileira é composta de 24,5 milhões de pessoas com necessidades especiais, sendo que apenas 325 mil estão matriculados em escola inclusiva. Mesmo considerando as pessoas especiais que estão fora da faixa etária para serem matriculadas, é muito baixo o número de alunos matriculados na escola. Mesmo com o aumento de matriculas inclusivas entre 2002 e 2006, ainda é acanhado o acesso dos alunos com necessidade educacional especial (ANEE). Faz-se necessário e urgente garantir a todos os alunos com NEE o acesso à escola inclusiva, numa perspectiva de oportunizar a aprendizagem e o desenvolvimento e, sobretudo a inserção no meio social.

O estudo sobre a ocupação do espaço escolar pelos alunos com necessidade educacional especial contribui para uma discussão sobre o tema da inclusão escolar com vista na procura e na permanência dos mesmos.

A inclusão escolar tem como pressuposto a igualdade dos direitos humanos, baseado no respeito à diversidade. Vale ressaltar que conviver numa sociedade marcada por diferenças humanas é o início de um novo tempo para o desenvolvimento humano e quando compartilhamos espaços comuns permitimo-nos crescer como pessoas, por meio das trocas de experiências vivenciadas, especialmente o espaço escolar que há uma maior acessibilidade e onde a interação social é intensa.

Embora reconhecendo o crescimento social do Brasil nos últimos anos, ainda há uma população à margem da sociedade, lutando para ser inserida efetivamente. Investir na qualidade de ensino é também investir na inclusão 
escolar, numa perspectiva de oportunizar a todos o direito de aprender e respeitar, sobretudo a individualidade de cada um.

A inclusão escolar traz para a sociedade uma nova possibilidade de interação, uma oportunidade de trocas de experiências entre as pessoas. $O$ espaço da escola representa um lugar mais democrático e mais acessível, onde as diferenças podem ser vistas com outro olhar. É preciso percorrer todos os espaços possíveis para alcançar e conquistar uma sociedade que reconheça efetivamente as diferenças como parte da complexidade humana.

Diante do quadro de inclusão, as pessoas devem estar atentas e unidas para participar ativamente deste novo modelo social que emana de uma necessidade concreta da sociedade, em compreender e aceitar a diversidade humana e de inserir todos os cidadãos no contexto em que se encontra. 


\section{REFERÊNCIAS}

AMARAL, Suely Aparecida. Estágio Categorial. In: Psicologia Educação Henri Wallon. São Paulo: Edição Loyola. 2002.

BAUER, Martin W. \& GASKELL, George G. Pesquisa qualitativo com texto, imagem e som: um manual prático. 5ed. Rio de Janeiro: Vozes, 2000.

Brasil. IBGE. Censo Demográfico. 2000. Disponível em <http://www.ibge.gov.br/home/estatistica/populacao/censo2000/default>. Acesso em: 20 de Janeiro de 2011.

Brasil. INEP. Censo Escolar. 2006. Disponível em $<$ http://www.inep.gov.br/basico/censo/default.asp>. Acesso em: 20 de Janeiro de 2011.

Brasil, Ministério da Educação. Diretrizes nacionais para a educação especial na educação básica. Secretaria de Educação Especial - MEC/ SEESP, 2001.

CARLOS, Ana Fani Alessandri. O Lugar no/do Mundo. São Paulo, Hucitec, 1996.

CARVALHO, Rosita Edler. Removendo barreiras para a aprendizagem: educação inclusiva. Porto Alegre: Mediação, 2002.

CARVALHO, Rosita Edler. Temas em educação especial. Rio de Janeiro: WVA, 2003.

CAVALCANTE, Meire. As leis sobre diversidade. Nova Escola: Inclusão. Edição Especial. São Paulo. Abril. P. 14-15, 2006.

CHRAIM, Albertina de Mattos. Família e Escola: A arte de aprender para ensinar. Rio de Janeiro: WAK, 2009.

CORRÊA, Roberto Lobato. Geografia: Conceitos e Temas. Rio de Janeiro: Bertrand, 1995.

CORRER, Rinaldo. Deficiência e inclusão social: construindo uma nova comunidade. Bauru, SP. EDUCS.2003.

FREIRE, Paulo. Educação e mudança. São Paulo: Paz e Terra, 1979. 
FURTH, Hans G. Piaget na sala de aula. Rio de Janeiro. Forense Universitária, 2007.

GOULART, Iris Barbosa. Piaget: Experiências básicas para utilização pelo professor. Petrópolis: Vozes, 1983.

MACHADO, Rosângela. Educação Especial na Escola Inclusiva: Políticas, Paradigmas e Práticas. São Paulo: Cortez, 2009.

MARTINS, Joel \& BICUDO, Maria Aparecida Viggiani. A Pesquisa Qualitativa em Psicologia: Fundamentos e Recursos Básicos. São Paulo: Centauro, 2005

MIZUKAMI, Maria da Graça Nicoletti. Ensino: As Abordagens do Processo: Temas Básicos de Educação e Ensino. São Paulo: EPU, 1986.

NOGUEIRA, Ana Lúcia Horta. A linguagem e o outro no Espaço Escolar: Vygotsky e a construção do conhecimento. Campinas, SP: Papirus,1995.

OGAMA, Maria Aparecida Gerra \& TANAKA, Eliza Dieko Oshiro. Família e Instituição para portadores de Deficiência Mental - da expectativa do primeiro contato à realidade. In: $\mathrm{O}$ Papel da família junto ao portador de necessidades especiais. Londrina: Eduel. 2003.

OLIVEIRA, Marta Kohl. Vygotsky: Aprendizado e desenvolvimento um processo sócio-histórico. São Paulo: Scipione.1993.

PACHECO, José. Caminhos para a inclusão: um guia para o aprimoramento da equipe escolar. São Paulo: Artmed, 2007.

PAMPLIN, Renata Christian de Oliveira \& SIGOLO, Silvia Regina Ricco Lucato. Relações Díadicas no Contexto Familiar de Crianças com Necessidades Educacionais Especiais. In: O Papel da família junto ao portador de necessidades especiais. Londrina: Eduel. 2003.

PILETTI, Nelson. Psicologia Educacional. São Paulo: Editora Ática, 1991.

RAPOSO, Patrícia Neves \& CARVALHO, Erenice Natália S. de. Inclusão de alunos com deficiência visual. Ensaios Pedagógicos: Construindo escolas inclusivas. MEC. Brasília, 2005.

REGO, Teresa Cristina. Vygotsky: Uma Perspectiva Histórico-Cultural da Educação. Petrópolis, Vozes, 2001.

SECRETARIA DE EDUCAÇÃO ESPECIAL / MEC. A inclusão escolar de alunos com necessidades educacionais especiais: Deficiência Física. Brasília, 2006. 
SECRETARIA DE EDUCAÇÃO INCLUSIVA / MEC. Documento subsidiário à política de inclusão. Ministério da Educação. Brasília, 2005.

SECRETARIA DE EDUCAÇÃO INCLUSIVA / MEC. Programa Educação Inclusiva: direito à diversidade: Experiências Educacionais Inclusivas, Ministério da Educação. Brasília, 2006.

SECRETARIA DE ESTADO DA EDUCAÇÃO DO RIO GANDE DO SUL. Planejamento participativo: Caderno Temático da Constituição Escolar 2. 2000.

SIMÃO, Antoinette \& SIMÃO, Flávia. Inclusão: Educação Especial - Educação Essencial. São Paulo: Cia dos Livros, 2010.

SZYMANSKI, Heloisa. A relação família/escola: Desafios e perspectivas. Brasília. Liber Livro, 2010.

TUNES, Elizabeth; TACCA, Maria Carmen Villela Rosa \& MARTINEZ, Albertina Mitjáns. Uma crítica às teorias clássicas da aprendizagem e à sua expressão no campo educativo. Linhas críticas. V. 12, n.22. Brasília, 2006. 
APÊNDICES 
APÊNDICE A

ROTEIRO DE ENTREVISTA SEMIESTRUTURADA APLICADA AOS PROFESSORES

Identificação do professor:

1. Sexo:

( ) Masculino ( ) Feminino

2. Idade:

3. Estado civil: Tem filhos? Quantos?

4. Situação funcional na SEEDF:
( ) efetivo
( ) contrato temporário

5. Formação acadêmica:

( ) Ensino Médio

( ) Magistério

( ) Superior incompleto

( ) Superior completo

( ) Especialização

( ) Mestrado

( ) Doutorado

Em qual

área:

6. Tempo de docência na SEEDF:

7. Tempo de docência com alunos com necessidades educacionais especiais:

8. Você atua em turmas:

( ) do Ensino Regular

( ) do Ensino Regular com ANEEs inclusos

( ) do Ensino Especial

9. Quantos alunos com NEE têm em sua sala de aula? 


\section{Roteiro de perguntas para o professor regente:}

1. O que você acha do processo de inclusão escolar da sua escola?

2. Qual a importância que você dá ao espaço escolar, pensando no desenvolvimento do aluno com NEE?

3- Ao receber um aluno com necessidade educacional especial quais são os cuidados tomados em sua sala de aula, visando receptividade desse aluno?

4- Que procedimento(s) você usa para promover a integração do aluno com NEE em sua sala de aula?

5- Qual/quais aspectos você leva em consideração no momento de realizar a avaliação do aluno com NEE?

6- Como se dá a participação da família na escola e no processo de ensino aprendizagem do aluno com NEE? A escola facilita essa participação da família? Como?

7- De acordo com sua experiência, qual a atribuição/valor os alunos com NEE dão ao espaço escolar?

8- Como é a relação dos demais alunos com seu aluno com NEE?

9- Diga quais foram as maiores dificuldades no processo de inclusão aqui na sua escola, bem como os avanços conquistados.

10- Em sua opinião, o que precisar ser feito para termos uma educação efetivamente inclusiva?

\section{Roteiro de perguntas para o professor da sala de recurso:}

1- Na sua visão quais são os aspectos mais importantes da escola inclusiva na vida dos alunos com NEE?

2- Como é feito o apoio pedagógico na sala de recurso para auxiliar o processo de ensino aprendizagem do aluno com NEE?

3- Como ocorre a interação do(s) professor(es) da sala de aula com a sala de recursos?

4- Você considera que o espaço da escola pode facilitar a promoção do aluno com NEE, num contexto de inclusão social mais amplo? Por quê? 


\section{APÊNDICE B}

\section{ROTEIRO DE ENTREVISTA SEMIESTRUTURADA APLICADA AS FAMÍLIAS}

Idade:

Estado

civil:

Quantos

filhos?

Qual deles tem Necessidades Especiais?

\section{Roteiro de Entrevista semi-estruturada}

1- Qual é a importância do espaço escolar na vida de seu filho com NEE?

2- Para você e para o seu filho com NEE a escola representa o quê?

3- Como a escola promove a participação da família no processo de aprendizagem de seu filho?

4- Como a família participa da vida escolar de seu filho com NEE?

5- Quais são as maiores dificuldades enfrentadas pela família ao trazer o aluno com NEE para a escola?

6- Em sua opinião, quais foram (ou são) as maiores dificuldades encontradas no processo de inclusão escolar de seu filho e quais foram os avanços conquistados? 


\section{APÊNDICE C}

\section{ROTEIRO DE ENTREVISTA SEMIESTRUTURADA APLICADA AOS ANEES}

Idade:

Quantos irmãos você possui:

Qual a deficiência:

1- É bom estudar nesta escola:
( ) Sim
( ) Não

2-Você gosta da hora do intervalo (recreio):
( ) Sim
( ) Não

3-Seus colegas ficam com você na hora do intervalo:
( ) Sim
( ) Não

4- Seu professor facilita a sua participação nas aulas:
( ) Sim
( ) Não

5- Quando você necessita de alguma ajuda solicita a quem:
( ) Professor
( ) Colega
( ) Monitor

6- O que você faz na hora do recreio?

7- Com quem você vem para a escola?

8- O que você mais gosta de fazer na escola? E o que menos gosta?

9- Você acha muito importante vir à escola? Por quê? 


\section{APÊNDICE D}

\section{ROTEIRO DE OBSERVAÇÃO}

- A relação do professor com os seus alunos, com destaque ao aluno NEE;

- A relação dos alunos com NEE com os demais;

- A relação dos alunos com NEE com os demais alunos na hora do recreio;

- A relação da família dos alunos com NEE com os professores de seu filho e com os profissionais da escola.

- A relação dos profissionais da escola com os alunos com NEE. 
ANEXOS 


\section{ANEXO A}

\section{CARTA DE APRESENTAÇÃO}

Universidade de Brasília - UnB

Instituto de Psicologia - IP

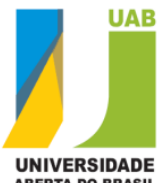

Departamento de Psicologia Escolar e do Desenvolvimento - PヒU

Programa de Pós-Graduação em Processos de Desenvolvimento Humano e Saúde PG-PDS

Curso de Especialização em Desenvolvimento Humano, Educação e Inclusão Escolar

A(o) Diretor(a) da Escola Centro de Ensino Fundamental no 01 do Lago Norte CELAN

De: Profa. Dra. Diva Albuquerque Maciel

Coordenadora Geral do Curso de Especialização em Desenvolvimento Humano, Educação e Inclusão Escolar

\section{Assunto: Coleta de Dados para Monografia}

Senhor (a), Diretor (a),

A Universidade Aberta do Brasil - Universidade de Brasília está em processo de realização da $1^{\underline{a}}$ oferta do curso de Especialização em Desenvolvimento Humano, Educação e Inclusão Escolar, do qual seis dentre as 20 turmas ofertadas são de professores e educadores da rede pública do DF (Pólos UAB-UnB de Santa Maria e Ceilândia). Finalizamos agora a $1^{\text {a }}$ fase do curso e estamos iniciando a Orientação de Monografia.

É requisito parcial para a conclusão do curso, a realização de um estudo empírico sobre tema acerca da inclusão no contexto escolar, cujas estratégias metodológicas podem envolver: entrevista com colegas, pais ou outros participantes; observação; e análise documental. 
A realização desses trabalhos tem como objetivo a formação continuada dos professores/servidores da rede pública, subsidiando-os no desenvolvimento de uma prática pedagógica refletida e transformadora, tendo como consequência uma educação inclusiva.

O trabalho, a ser desenvolvido na escola sob sua direção, será realizado pelo Professor/cursista Maura Cacilda Cabral Machado, cujo tema de pesquisa é: A participação da família e dos alunos com necessidades educacionais especiais no espaço escolar, numa perspectiva de promover à inclusão social, sob orientação da profa. Rute Nogueira de Morais Bicalho.

Desde já agradeço, colocando-me a disposição de Vossa Senhoria para maiores esclarecimentos nos telefones. (061 8114-2995) ou por meio do email: arutebicalho@gmail.com

Atenciosamente,

\section{Diva Albuquerque Maciel}

Coordenadora Geral do Curso de Especialização em Desenvolvimento Humano, Educação e Inclusão Escolar 


\section{ANEXO B \\ TERMO DE CONSENTIMENTO LIVRE E ESCLARECIDO}

Universidade de Brasília - UnB

Instituto de Psicologia - IP

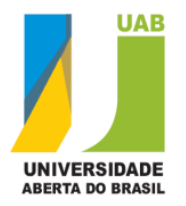

Departamento de Psicologia Escolar e do Desenvolvimento - PED

Curso de Especialização em Desenvolvimento Humano, Educação e Inclusão Escolar

Senhores Professores,

Sou orientanda do Curso de Especialização em Desenvolvimento Humano, Educação e Inclusão Escolar, realizado pelo Instituto de Psicologia por meio da Universidade Aberta do Brasil- Universidade de Brasília (UABUnB) e estou realizando um estudo sobre a participação da família e dos alunos com necessidades educacionais especiais no espaço escolar, numa perspectiva de promover à inclusão social. Este estudo poderá fornecer às instituições de ensino subsídios para o planejamento de atividades com vistas à promoção de condições favoráveis ao pleno desenvolvimento dos alunos em contextos inclusivos e, ainda, favorecer o processo de formação continuada dos professores nesse contexto de ensino.

Constam da pesquisa entrevistas gravadas em áudio com os educadores no intuito de adquirir maior conhecimento sobre o tema e para enriquecer a pesquisa. Para isso, solicito sua autorização para participação no estudo.

Esclareço que a participação no estudo é voluntária. Você poderá deixar a pesquisa a qualquer momento que desejar e isso não acarretará qualquer prejuízo a você. Asseguro-Ihe que sua identificação não será divulgada em hipótese alguma e que os dados obtidos serão mantidos em total sigilo, sendo analisados coletivamente. 
Caso tenha alguma dúvida sobre o estudo, o(a) senhor(a) poderá me contatar pelo telefone (61) 81282545 - 92423961 e 30453961 ou no endereço eletrônico mauracabral13@yahoo.com.br. Se tiver interesse em conhecer os resultados desta pesquisa, por favor, indique um e-mail de contato.

Agradeço antecipadamente sua atenção e colaboração.

Respeitosamente,

Orientando Maura Cacilda Cabral Machado (UAB - UnB)

Concorda em participar do estudo? ( ) Sim ( ) Não

Nome:

Assinatura:

E-mail

(opcional): 


\section{TERMO DE CONSENTIMENTO LIVRE E ESCLARECIDO - PAIS}

\section{Universidade de Brasília - UnB}

Instituto de Psicologia - IP

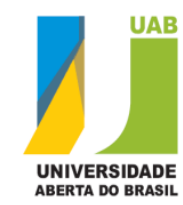

Departamento de Psicologia Escolar e do Desenvolvimento - PED

Curso de Especialização em Desenvolvimento Humano, Educação e Inclusão Escolar

Senhores Pais ou Responsáveis,

Sou orientanda do Curso de Especialização em Desenvolvimento Humano, Educação e Inclusão Escolar, realizado pelo Instituto de Psicologia por meio da Universidade Aberta do Brasil- Universidade de Brasília (UABUnB) e estou realizando um estudo sobre a participação da família e dos alunos com necessidades educacionais especiais no espaço escolar, numa perspectiva de promover à inclusão social. Este estudo poderá fornecer às instituições de ensino subsídios para o planejamento de atividades com vistas à promoção de condições favoráveis ao pleno desenvolvimento dos alunos em contextos inclusivos e, ainda, favorecer o processo de formação continuada dos professores nesse contexto de ensino.

Constam da pesquisa entrevistas gravadas em áudio com os alunos, pais e professores no intuito de adquirir mais conhecimentos sobre o tema e para enriquecer a pesquisa. Para isso, solicito sua autorização para participação no estudo.

Para isso, solicito sua autorização para que seu(sua) filho(a) participe do estudo.

Esclareço que a participação no estudo é voluntária. Seu(sua) filho(a) poderá deixar a pesquisa a qualquer momento que desejar e isso não acarretará qualquer prejuízo ou alteração dos serviços disponibilizados pela escola. Asseguro-Ihe que a identificação de seu(sua) filho(a) não será 
divulgada em hipótese alguma e que os dados obtidos serão mantidos em total sigilo, sendo analisados coletivamente.

Caso tenha alguma dúvida sobre o estudo, o(a) senhor(a) poderá me contatar pelo telefone (61) 81282545 - 92423961 e 30453961 ou no endereço eletrônico mauracabral13@yahoo.com.br. Se tiver interesse em conhecer os resultados desta pesquisa, por favor, indique um e-mail de contato.

Agradeço antecipadamente sua atenção e colaboração.

Respeitosamente,

Orientanda Maura Cacilda Cabral Machado - UAB - UnB

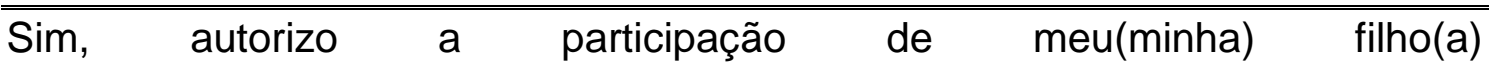

neste estudo.

Nome:

Assinatura:

E-mail (opcional): 


\section{ANEXO C \\ TRANSCRIÇÃO DAS ENTREVISTAS}

\section{Entrevista 1 - Com a professora da sala de recursos - deficientes visuais}

1-Na sua visão quais são os aspectos mais importantes da escola inclusiva na vida dos alunos com NEE?

Eu acho que os aspectos, um dos aspectos mais importantes é... eu acho que é aquele primeiro espaço mesmo, dos alunos terem o contato com as outras crianças e passarem a ser respeitadas, conhecidas. Porque eles trabalham juntos, eles mostram as capacidades... que eles conseguem fazer. Muitas crianças não tinham contato com aluno especial. Aí com essa oportunidade eles vêem que eles são crianças completamente capazes de participar de tudo, que eles fazem, sabe? Precisam de algumas adaptações, no caso de deficiente visual tem que ter material adaptado, tem de ter uma certa orientação do espaço da escola, mas depois que eles tem essas questões trabalhadas eles participam de tudo.

2- Como é feito o apoio pedagógico na sala de recursos para auxiliar 0 processo de ensino aprendizagem do aluno com NEE?

$\mathrm{Na}$ sala de recursos ela atende o aluno no horário contrário do de aula, eles vem uma ou duas vezes na semana para o atendimento. E nós trabalhamos as questões complementares do trabalho pedagógico do tipo, reforço, o braile, a gente trabalha orientação e mobilidade para eles aprenderem a se locomover sozinhos pela escola, a gente dar aula de soroban... "é como se fosse um ábaco que eles utilizam para fazer tudo em matemática, então assim, a gene trabalha esses atendimentos complementares com os alunos.

3- Como ocorre a interação do(s) professor(es) da sala de aula com a sala de recursos?

È um trabalho constante. Tem que ser um trabalho que anda junto. Os professores passam para a gente todos os materiais que eles vão precisar trabalhar com o aluno e a gente faz as adaptações. A gente senta com o professor e fala que esta é a melhor forma de adaptar esse material para o aluno aprender em sala de aula. Então a gente tá sempre em contato para fazer essa ponte e o aluno aprender em sala de aula o conteúdo. Esse contato 
se dá no dia a dia, na coordenação dos professores. A sala está sempre aberta. O professor precisa alguma coisa na hora ele vem aqui. A gente entra na sala de aula, na coordenação o professor chama a gente, olha! Como eu vou trabalhar esta questão com o aluno? A gente sugere alguma atividade adaptativa. Constante é o contato.

4- Qual a importância que você dá ao espaço escolar, pensando no desenvolvimento do aluno com NEE?

Eu acho que o espaço escolar ele é importantíssimo. Porque aqui o aluno vai fazer suas relações sociais, suas primeiras relações sociais. Aqui ele faz passeios fora da escola, eles começam a ter mais segurança no relacionamento com as outras pessoas, que eles chegam aqui tímidos, com medo, tanto a família tem medo quando os alunos. Os próprios alunos com necessidades especiais vêm também com um pouco de medo, insegurança. Os pais ficam preocupados se seus filhos vão se adaptar, se vão ser bem recebidos, se vão ter amigos, se vão consegui. Mas é tranqüilo as crianças, sabe! querem ajudar, querem brincar. Hoje eles convivem, sabem respeitar, sabem como lidar. Os nossos alunos deficientes visuais eles tiram notas maiores do que os outros alunos que enxergam. Então isso é bom para eles perceberem também que eles são capazes, são inteligentes.

5- Você considera que o espaço da escola pode facilitar a promoção do aluno com NEE, num contexto de inclusão social mais amplo? Por quê?

Com certeza. Aos poucos ele ir sendo inserido, depois ir para o mercado de trabalho. A preparação inicial deles é na escola.

6- Como se dá a participação da família na escola e no processo de ensino aprendizagem do aluno com NEE? A escola facilita essa participação da família? Como?

Olha! Aqui na nossa escola com relação aos alunos deficientes visuais a gente procura tá sempre em contato com os pais, fazendo sensibilização, dos pais estarem sempre presentes nas reuniões, de deixarem os filhos irem a passeios. Que a gente coloca que essa questão deles participarem de todas as atividades da escola é muito importante para ele. E tem pais que tem medo de deixarem os filhos sair, brincar... sabe, então é assim, a gente tá sempre em contato com os pais, reforçando a importância deles participarem juntos, tem passeios que os pais podem ir juntos. A escola tá sempre de portas abertas. Tem pai que passa o dia inteiro esperando o filho, ainda mais deficiente visual, 
a criança não anda sozinha, então os pais ficam na escola, esperando o filho, almoçam por aqui já. A mãe deixa de trabalhar para ficar cuidando do filho. Os pais presentes que a gente sabe que em casa eles chegam e dá continuidade ao que a gente oriente aqui na escola agente sabe que os filhos deles são bem mais motivados. Porque sabem que tem alguém que vai cobrar, que vai olhar, que vai perguntar, que tem interesse. Com certeza ajuda muito.

7-De acordo com sua experiência, qual a atribuição/valor que os alunos com NEE dão ao espaço escolar?

Os alunos com necessidade especial eles amam vir para a escola que é o momento que eles brincam, que eles conversam com os amigos, eles trocam idéias com a gente também. Principalmente os deficientes visuais eles são muito tímidos, são muito fechados, eles não saem para brincar na rua, eles não tem uma vida social... eles são mais limitados, eles ficam brincando sozinhos em casa. Então chegam na escola é hora que eles tem para extravasar é o momento deles também de além de aprender que eles são/também gostam de estudar, tem interesse, é o momento que eles tem para conversar com os colegas, para correr no pátio com os meninos, sabe! é o momento de interagir mesmo com outras crianças.

8- Diga quais foram as maiores dificuldades no processo de inclusão aqui na sua escola, bem como os avanços conquistados.

Nossa maior dificuldade era questão de recursos materiais que a sala não tinha nada, a gente fazia material usando a máquina braile, aquela máquina pesada, então era assim. Fazia livro, prova tudo usando aquela máquina. Tem uns 6 a 7 anos. Agente fazia ampliação na mão, não tinha computador. Então assim, esses equipamentos que nossa sala tem hoje com certeza isso aí foi um avanço muito grande. Ainda tem mais coisas, lógico que a gente podia ter porque tem muitos recursos tecnológicos que a gente ainda não tem acesso que são coisas caras e tal, mas o que a gente já tem em comparação o que era já foi um avanço enorme.

Fora a questão material como é a receptividade dos alunos com necessidade especial em relação a escola com todos os envolvidos? Hoje em dia eu acho que é mais fácil de todo mundo aceitar a questão do aluno com necessidade especial porque já tá mais divulgado, já se fala mais nisso porque antigamente o professor vinha para a escola quando tinha um aluno na sala dele com deficiência ele escolhia e não ficava naquela sala. Ele podia escolher. Hoje nem isso pode mais e eu acho certo isso. Você tem que gostar, não sabe? vai 
atrás. Realmente falta curso de capacitação o professor também hoje tem que ir atrás de algumas coisas.

9- Em sua opinião, o que precisa ser feito para termos uma educação efetivamente inclusiva?

Tudo que tá no papel tem que sair e vir para a prática que a lei no papel é fantástica! Eles são amparados em tudo né? Mas só que na prática a gente ver que isso não acontece. Agente tem que ir plantando essa semente, então sabe, de grãozinho em grãozinho, falando todo dia, batendo na mesma tecla, conversando, sensibilizando, falando todo dia.

\section{Entrevista 2 - Com a professora da sala de aula inclusiva}

1- O que você acha do processo de inclusão escolar da sua escola?

Acho que ele acontece naturalmente. Aqui a gente tem duas turmas de ensino especial e a nossa escola recebe os alunos que vem do centro de ensino de deficiência visual né nós temos aqui alunos Down e muitos alunos com deficiência visual e outros alunos com outras com morbidades e recebemos também alunos de fora, nos processos de remanejamento e rematrícula e agente recepciona esses meninos como manda a lei, digamos assim.

2- Qual a importância que você dá ao espaço escolar, pensando no desenvolvimento do aluno com NEE?

Eu acho que o espaço escolar é fundamental para esse desenvolvimento tanto para o aluno especial quanto os ditos normais. O espaço escolar ele é rico né em estímulos em oportunidades para essas crianças desenvolverem em todas as áreas de aprendizagem dela.

3- Ao receber um aluno com necessidade educacional especial quais são os cuidados tomados em sua sala de aula, visando receptividade desse aluno?

Bom aqui na escola os alunos, aqui a gente atende alunos de primeiro ano a quinto ano. Então assim quando eles entram aqui no primeiro ano, eu nunca dei aula no primeiro ano aqui nessa escola, mas eu creio que as colegas façam um trabalho de sensibilizar os outros alunos para essas deficiências, quando essa deficiência é evidente como a deficiência visual, a Síndrome de Down para os demais alunos perceberem essas diferenças e aceitar sem preconceitos essa criança. Então no caso, só a título de exemplo, esse ano eu to com o segundo ano que era a antiga terceira série e muitos dos meus alunos já estudaram juntos no primeiro ano e no segundo ano e eu não percebo assim dificuldade deles receberem os colegas que tem alguma deficiência algum tipo de deficiência não. Mas quando chega algum colega novo independente até de 
ter alguma deficiência eu tenho o trabalho de conversar de apresentar eu peço para eles se apresentarem a escola pro colega. No segundo semestre foi interessante que chegou um aluno na minha sala é japonês, ele mora no Brasil ele fala português aí eu fui me dá conta que na nossa escola não tem um aluno oriental então foi assim a escola inteira ficou encantada pegava nele é especial no sentido de ser diferente dos demais e na hora do recreio a gente até alguns problemas porque os meninos tocavam nele como se ele fosse de outro planeta sabe e aí a gente conversou muito em sala que ele tinha outra cultura mas que ele também tinha aprendido a cultura brasileira porque ele mora aqui desde bebe e ele teve oportunidade de aprender também a nossa cultura ele também fala um pouco do que ele sabe do japonês.

4- Que procedimento(s) você usa para promover a integração do aluno com NEE em sua sala de aula?

Olha em termos sociais é isso que eu falei na pergunta anterior, em termos pedagógicos é preparar o material adaptado, é... fazer ele participar de alguma atividade oralmente. Esse ano nós tivemos a sorte, por exemplo, de ter aulas com alunos do curso de música da UnB e foi um momento muito legal por exemplo que meu aluno que é deficiente visual que é super tímido e retraído se soltar um pouco sabe começar a rir interagir com os outros. Fora esses momentos esporádicos, no caso da aula de musicalização foi um privilegio é tentar o fazer ele participar das brincadeiras todas as atividades que eu proponho para os outros alunos incluir ele nessa atividades também.

5- Qual/quais aspectos você leva em consideração no momento de realizar a avaliação do aluno com NEE?

Olha na secretaria de educação os alunos com necessidades especiais eles têm direito a adequação curricular. Que é adequação curricular é você fazer uma avaliação do que o aluno é capaz de oferecer do que ele é capaz de aprender naquele tempo. E aé esse tempo pode ser um bimestre, pode ser um semestre, normalmente aqui na escola agente faz por semestre. Então quer dizer de tudo que você tem que trabalhar para que as crianças adquiram aquelas habilidades e competências o que você julga que é fundamental e 0 que você acha que ele vai conseguir. Não pode também resumir ao mínico porque muitas crianças que extrapolam o mínimo que muitas vezes você coloca. Então em termos de avaliação é estabelecer critérios de acordo com a deficiência e com as habilidades que a criança já tem e estimular ela para conseguir o máximo possível dentro daquilo ali, entendeu? E no ato digamos assim de uma prova mesmo é você avaliar se há necessidade de suprimir alguma questão ou de diminuir a quantidade ou de dar mais tempo para essa criança realizar essa prova, no caso de meu aluno deficiente visual ele faz até quando as crianças começam a me entregar as avaliações, se ele ainda não terminou, ele vai para a sala de recursos e termina sozinho na sala de recursos 
para que seja garantido a ele um espaço do ambiente com silencio, entendeu? é esse tipo de coisa que a gente faz.

6-Como se dá a participação da família na escola e no processo de ensino aprendizagem do aluno com NEE? A escola facilita essa participação da família? De que forma?

È! Olha! eu acho que assim não dá para generalizar não. Até porque se eu fosse generalizar aminha avaliação com relação a participação da família ia ser negativa não por uma questão das crianças terem necessidades especiais, mas eu acho de um modo geral a família tá muito ausente da vida escola das crianças. Então assim eu tenho três alunos com diagnóstico com necessidades especiais, um com deficiência visual que é só ele e a mãe e a mãe também é deficiente visual e ela ajuda no que pode, um é com TDAH, transtorno déficit de atenção e hiperatividade que no meu ponto de vista o problema da criança ou os problemas da criança decorrem da própria família da estrutura familiar e o terceiro que tem dislexia o pai é analfabeto, a mãe é analfabeta e também não tem muito como contar muito com a família você tá entendendo? Aí é complicado a gente favorece? Favorece. A gente convoca para reunião, a gente convoca para conselho, mas a participação é pequena. $E$ assim, eu acho que é mera coincidência quando o aluno tem alguma dificuldade de aprendizagem, mesmo que ele não seja diagnosticado um aluno especial, que a origem disso não venha da família. Normalmente tem alguma coisa a ver.

7-De acordo com sua experiência, qual a atribuição/valor que os alunos com NEE dão ao espaço escolar?

Olha! Difícil responder. Eu acho pode ser um aluno que tenha alguma... que são especiais que o cognitivo é preservando... você tá entendendo? Eu acho que eles dão o devido valor, que a escola é o lugar pra ir, pra aprender, pra fazer atividades, pra aprender a ler, pra aprender a escrever, pra fazer continhas, pra resolver problemas. Agora quando o aluno tem algum problema, um comprometimento maior aí eu não sei se ele tem alguma noção, que valor eles dão pro espaço. Talvez seja mais o valor social mais que pese mais nessa hora, dele se socializar, de conhecer outras crianças, dele se relacionar, de encontrar até mesmo crianças com a mesma deficiência, entendeu? Num espaço diferente do da casa, por exemplo, no espaço que ele domina. Eu acho que tudo que o aluno traz pra escola é reflexo do que ele aprende ou até desaprende (riso) na família, se a família dá valor, participa, cobra inclusive da escola comprometimento com a criança e tudo mais o próprio aluno tem uma resposta mais positiva, agora quando a família entrega como muitos casos ver a escola como um lugar para deixar o filho especial que não tem com quem 
deixar aí realmente talvez essa criança a escola tenha esse valor para ser um lugar para ficar e mais nada.

8- Como é a relação dos demais alunos com seu aluno com NEE?

Olha o deficiente visual que é uma deficiência evidente assim que eles percebem, é ótimo né? Só não é melhor porque o próprio aluno tem, digamos assim, não é que ele tenha rejeição com a deficiência, mas ele tem dificuldade de superar, ele é muito tímido, retraído, ele não fala se você não conversar com ele, você tá entendendo? Mas mesmo assim as crianças se aproximam, brincam, fazem questão que ele participe, fazem questão que faça parte de grupo, quando a atividade é em grupo. Ele tem 10 anos de idade e os outros dois não são deficiências evidentes, interagem com os outros de igual para igual não tem diferença nenhuma.

9-Diga quais foram as maiores dificuldades no processo de inclusão aqui na sua escola, bem como os avanços conquistados.

Olha quando eu cheguei aqui há quatro anos o histórico de inclusão dessa escola já vem de mais de 10 anos, então eu cheguei aqui esse processo já estava aqui que meio instaurado, então eu não participei do processo em que esse processo de inclusão estava chegando ele já exista. Como aqui na escola tem duas turmas de ensino especial e tem também o histórico de recepcionar também o aluno do centro de ensino especial de deficiência visual, isso aqui não tem grandes dificuldades, tem dificuldade sim, quando a gente acha que 0 aluno não tem a base mínima pra vim, ou quando a gente acha que o aluno deve continuar no centro e ele veio para cá, né? Então é assim, é só casos esporádicos e assim pontuais entendeu? De um modo geral a inclusão aqui acontece a contento, dento do que a secretaria oferece pra gente. Eu acho que a secretaria tinha que investir mais na qualificação dos profissionais. Eu acho que a inclusão dos alunos especiais ela é uma questão muito séria e a secretaria não dá devida seriedade. O professor tem de ter perfil para trabalhar com o ensino especial, não é todo professor que tem perfil, às vezes até tem o conhecimento, mas não tem o perfil e tem outra, são muitas áreas, então tem o down, tem o que é cadeirante, tem o deficiente visual, tem o que é condutas típicas, sabe e o professor da sala regular ele já tem que dá conta de muitos alunos e ainda se especializar em alguma deficiência, alguma área especifica. Sabe, então eu acho assim que tem alguma negligencia com o professor, com as crianças e com a família também. Os avanços eu acho que avanço para as crianças, o ganho delas porque toda vez que a gente recebe uma noticia como eu havia conversado com você que a próxima estratégia de matriculas uma classe especial aqui da nossa escola pode ter até 18 alunos especiais com diferentes com morbidades com um único professor, isso no mínimo para mim é desumano, é desrespeitoso com o professor, com o aluno, com a família com todo mundo. Então assim os avanços eu não consigo ver de um modo mais 
amplo. Eu vejo os avanços das crianças com elas mesmas, elas acabem crescendo com o convívio com as outras.

10-Em sua opinião, o que precisa ser feito para termos uma educação efetivamente inclusiva?

Eu acho que os professores tem que ser é... os professores tem que se candidatar, os professores tem que poder escolher a área em que querem atuar, a secretaria tem que fornecer formação profissional dentro daquela a área especifica é eu acho que o professor tem que ganha sim diferenciadamente porque ele faz um trabalho diferenciado as turmas tem que serem menores ainda. Quando o governo entrou ele divulgou para todos os cantos possíveis que as turmas iam diminuir, que as turmas iam ter 28 alunos, uma turma com 28 alunos, sendo que desses 28 , 3 podem ser alunos especiais de qualquer área né? Com qualquer com morbidade é muito, é muito, é sacrificante para o professor, para os demais alunos e pros alunos especiais. A secretaria precisa tratar a inclusão com seriedade, as escolas precisam estar preparadas, só as salas de recursos não tão dando conta do recado, não por uma questão de incompetência, mas por uma questão da demanda. Chegou mais de mil computadores, forma de dizer, computador, televisão de plasma e sabe falta tempo pra esse professor atender o aluno, muitas vezes os pais também não traz o aluno, a família tem que se envolver mais. A família pensa que a escola é deposito de crianças, que a gente tá aqui só para passar tempo com ele. Sabe, então tem uma série de coisas que tem que acontecer para a inclusão realmente acontecer com se prever no papel e acontecer como é o ideal de rodo mundo, de uma forma que todos ganhem, no momento eu acho que o ganho é muito pequeno e tem muito mais prejuízo.

\section{Entrevista 3 - Com a professora de sala de recursos - deficientes intelectuais}

1-Na sua visão quais são os aspectos mais importantes da escola inclusiva na vida dos alunos com NEE?

Olha a superação, a superação de barreiras, de limites, é ... a escola abre portas mesmo pra criança, oferece a criança as oportunidades para que ela cresça, os aspectos sociais, ela realmente começa a conviver com as pessoas, com crianças, interagem tudo isso é muito importante na vida, no crescimento global.

2- Como é feito o apoio pedagógico na sala de recursos para auxiliar o processo ensino aprendizagem do aluno com NEE?

Bom, aqui na sala de recursos nos trabalhamos com um foco maior no potencial da criança, do aluno, nos investimos nas suas potencialidades, não nas suas incapacidades. Nós procuramos conhecer cada aluno, as áreas de 
interesse, para encima disso a gente trabalha, outra coisa importante é nos trabalhamos também para o desenvolvimento da autonomia do aluno que para mim o desafio maior da inclusão é essa.

3- Como ocorre a interação do(s) professor(es) da sala de aula com a sala de recursos

A interação é muito grande, nos temos um parceria muito grande nós trabalhos juntas, fazemos adequação curricular juntas, as professoras se interessam muito pelo trabalho. Aqui é uma escola realmente inclusiva.

4- Qual é a importância que você dá ao espaço escolar, pensando no desenvolvimento do aluno com NEE?

Bom se a gente pudesse mensurar, dá uma nota, eu diria que uma nota 10 porque ele vai... é aprender, trocar experiências, ali vai ser oportunizado é... várias oficinas, é vivências, convivências, experiências novas com crianças diferentes, com professoras diferentes, conteúdos, habilidades diferentes.

5- Você considera que o espaço da escola pode facilitar a promoção do aluno com NEE, num contexto de inclusão social mais amplo? Por quê?

Pode. Porque é justamente tudo isso que eu vinha falando a escola oferece muita oportunidade de vivenciar de trocar experiência a criança, consegui ali com a interação com os outros aprender, ter modelos, criança principalmente nesta faixa etária quando está iniciando olha aqui com as outras na inclusão, quando está iniciando alfabetização é uma fase de imitar então elas imitam que os colegas falam e o colega faz então é um ambiente muito rico não é?

6- Como se dá a participação da família na escola e no processo de ensino aprendizagem do aluno com NEE? A escola facilita essa participação da família? Como?

Bom, uma das atribuições da professora de sala de recursos é essa de orientar a família, sobre os direitos, deveres, e a participação mesmo, a família conhece muito mais o aluno, a criança quando vem de casa vem de outra escola esse histórico pra nós de sala de recursos é muito importante então essa interação é feita em primeira mão pela família, sala de recursos e professora também e essa troca toda ajuda no processo de ensino aprendizagem da criança e melhora né o crescimento da criança vem muito mais forte quando todos ali participam se a professora sala de recursos detecta alguma coisa e fala pra professora, olha! vamos trabalhar assim, em casa trabalha do mesmo jeito então essa parceria toda gera um engrenagem e fica muito mais forte o crescimento do aluno.

7- De acordo com sua experiência, qual a atribuição/valor que os alunos com NEE dão ao espaço escolar? 
Olha, acho que aquela resposta até inicial a superação, em primeiro lugar eu colocaria que a superação de barreiras mesmo, você ver aqui é uma escola inclusiva de deficiente visual eles realmente aprendem a ler com a mão, faz 0 Bráulio maravilhoso, inclui realmente. Uma criança com deficiência intelectual tem a sensibilização, a troca de experiências isso tudo proporciona justamente isso as pessoas tem uma visão diferente começam a ter outra visão não só na incapacidade da criança e sim elas podem realmente crescer aprender e devem ser respeitados, o resgate, da quebra desse preconceito, de incapacidade, desse rótulo não é?

8- Diga quais foram as maiores dificuldade no processo de inclusão aqui na sua escola, bem como os avanços conquistados?

Olha é vamos falar das dificuldades é a própria dificuldade física vamos dizer assim para o deficiente visual $\mathrm{o}$ imobiliário fica fora do lugar pra deficiente visual. $O$ deficiente intelectual é aqui pro deficiente intelectual aqui sempre foi muito adequado é uma escola de braços abertos nós temos classes especiais os pais respeitam muito é há uma tomada de consciência geral as pessoas vamos dizer assim, tanto valorizam como dão força. Que bom que seu filho tá aqui! Compreendem, até promovem amizade olha vem aqui fulaninho olha aqui o amiguinho fulano você ajuda ate ajudam tem uma solidariedade muito grande. A dificuldade que eu posso nomear bem forte é o rotulo de incapacidade, isso de forma geral as pessoas vêem as crianças com Sindrome de Down com um olhinho puxado aquele ali é deficiente não sabe de nada não muitas vezes vão falar pra criança ao invés de reportar na criança ah qual o seu nome? Quantos anos você tem? Eles falam pra mãe para professora e não com a criança isso de não acreditar na criança, no aluno isso é a principal dificuldade não saber respeitar o ritmo próprio de cada criança isso também é uma coisa muito séria, são coisa que acontece na sociedade mas a gente ver mais fortemente na escola.

9- Em sua opinião, o que precisa ser feito para termos uma educação efetivamente inclusiva?

Olha. A inclusão ainda tá em processo, a inclusão é uma coisa muito mais ampla a gente precisa de políticas públicas uma coisa muito batida, muito falada, mas a gente precisa de política publica voltada pra inclusão precisamos também de mais esclarecimentos, mais incentivos mais conhecimento, as pessoas são muito desinformadas e mais envolvimento as pessoa não tem compromisso então falta tudo isso compromisso não só com a inclusão, mas com a educação de forma geral. Os professores muitos já estão com um olhar diferente, acreditando mais na capacidade, as mães, muitas mães hoje se mostram interessadas, incentivam os filhos acompanham os filhos hoje já temos uma melhor perspectiva para os especiais hoje é diferente já está bem melhor. 


\section{Entrevista 4 - Com a professora de classe especial - Deficiência Visual}

1- O que você acha do processo de inclusão escolar da sua escola?

Eu considero a minha escola privilegiada no processo de inclusão porque é uma escola até dita como modelo. Eu acho que aqui a inclusão acontece. Tem problemas? Tem. Mas acontece! Você vê que tem muitos alunos em sala de aula que tem sucesso, que tão aprendendo, que tão crescendo, que se beneficiam da inclusão. Eu acho que aqui a coisa acontece, a inclusão aqui é levada a sério a gente ver uma preocupação da direção com esses alunos, dos professores quando não são especializados correm atrás, buscam. Nós temos $2 \mathrm{~s}$ de recursos que ajudam muito. Eu acho que aqui a inclusão acontece tem problema tem, como tudo que está sendo implantado tem problemas.

2- Qual a importância que você dá ao espaço escolar, pensando no desenvolvimento do aluno com NEE?

Bom! Eu acho que no caso dos deficientes visuais o espaço tem que ser visto assim como primordial você não pode ter uma sala de aula, uma escola com obstáculos você precisa atentar para outras coisas pra sinalizadores no chão, não colocar nada encostado nas paredes, então tudo isso é importante, é fundamental para um deficiente visual poder se locomover dentro desse espaço para realmente a inclusão ocorrer eles ter acesso as coisas e ele se sentir independente nesse espaço que é importante para o desenvolvimento das crianças se sentir independentes se sentir útil aqui na sala eles tem aqui na sala logo que eu peguei essa turma a primeira coisa que eu procurei foi a disposição dos moveis para dá o máximo de espaço possível para eles andarem pela sala porque minha sala é muito pequena para eles poderem ter uma certa independência, então tem a estante onde eles guardam as mochilas deles sozinhos ele sabe onde fica uma lata de lixo, eles tem ali no cantinho de brincar no tapetinho que eles vão sozinhos tem acesso sozinho aos brinquedinhos eles vão sozinho ali no bebedouro, lavar a mão, alguns já vão sozinhos ao banheiro eu só fico mais preocupada assim ver se o banheiro está limpinho que eles não estão vendo para realmente sentar no lugar asseado. A minha preocupação maior de estar perto é mais para a segurança e com a higiene. $O$ resto é mais tranqüilo. Mas eles são bem independentes, acho que meus alunos são bem independentes, inclusive no recreio eles se sentem em casa não é?

3-Ao receber um aluno com necessidade educacional especial quais são os cuidados tomados em sua sala de aula, visando à receptividade desse aluno? 
Foi isso que eu falei, já respondi essa pergunta. Porque a primeira coisa que eu procurei foi uma boa disposição dos móveis e dá a ele autonomia eu apresentei o espaço pra ele olha aqui é nossa sala aqui fica isso, aqui fica aquilo, então mostrei onde ficam as coisas. Aqui nessa turma são 4 deficientes visuais, então apresentei o espaço a eles pra eles poderem se locomover ficar na sala e saber onde fica as coisas.

4-Que procedimento(s) você usa para promover a integração do aluno com NEE em sua sala de aula?

Bom na minha sala, no meu caso seria promover a integração com a escola né? Porque já que na minha turma é uma turma especial e todos estão na mesma situação. Eu tenho uma preocupação, inclusive uma vontade de desenvolver um projeto aqui no recreio porque eu me sinto assim meus alunos interagem entre eles ou entre outros alunos deficientes visuais. Então assim eu já levei jogos, bola pra promover essa integração, mas nem sempre ela acontece e nisso eu acho que a escola precisa olhar pra isso com mais cuidado sabe? eu acho que muitas vezes eles ficam isolados, mas de um modo geral a integração acontece tem algumas falhas ainda, por exemplo a escola promove atividades que você vê que é difícil incluis esses alunos, não só os deficiente visuais, mas também outros também, então eu acho que teria que ter mais cuidado com isso, às vezes tem ensaio lá fora, meus alunos já estão começando a ler o Bráulio, mas nem sempre é disponibilizado a lista do Bráulio pra eles, então eu já acho isso errado, eu acho que devia ter sempre que se pensar. Aí o que eu faço venho pra sala, pego a letra da música leio pra eles, digito com eles aproveito pra trabalhar a leitura e a escrita, faço o ditado e eles ficam com a música, levam pra casa ensaiam a música e eu aproveito como uma atividade, mas o certo é dá para todos os alunos, dá pra as outras turma e esquece dos meus.

5-Qual/quais os aspectos você leva em consideração no momento de realizar a avaliação do aluno com NEE?

Pra mim o mais importante na hora de eu avaliar um aluno com deficiente ou qualquer outro aluno, não só o NEE é o crescimento dessa criança o que é que ela desenvolveu, as potencialidades dele se ele chegou ao máximo que eu acho que o grande desafio do professor é ele vê como o seu aluno está no momento o que ele precisa e trabalhar diante disso o máximo do potencial dele, eu acho que a avaliação vai entrar aí saber se ele realmente atingiu 0 máximo que ele deveria atingir é assim que eu vejo a avaliação o aluno com ele mesmo o aluno com o crescimento dele principalmente nessa turma que é uma turma que é uma classe especial ela tem por objetivo trabalhar as potencialidades especificas daquele aluno, então eu trabalho é individual que eu peguei essa turma eu tenho aluno com baixa visão, aluno cego e cada num nível então eu trabalhava diversificado então hoje eles já estão todos e quem 
não esta alfabetizado tá quase alfabetizados então já tá dando pra trabalhar mais juntos, mas antes era individual o trabalho para poder atingir a todos eles.

6-Como se dá a participação da família na escola e no processo de ensino aprendizagem do aluno com NEE? A escola facilita essa participação da família? De que forma?

A escola promove reuniões periódicas que a família tem contato com o professor e também tem as festas que os pais vem sempre aqui, fora isso eu não vejo se tem alguma coisa mais que a escola faz eu desconheço ou estou até meio desinformada. Agora eu com relação a família dos meus alunos eu não tenho problemas eu tenho contato permanente, diário com os pais dos meus alunos porque como eles vem deixar os alunos na sala eu os vejo quase que diariamente, eu tenho o telefone de todos eles, então qualquer problema que eu tenho, inclusiva a $D$ tem problema renal e tem uma dieta rigorosa qualquer coisa eu ligo, olha o lanche é isso posso dá? Quanto eu posso dá? Então é assim eu tenho um ótimo relacionamento com todos os pais, quando eu preciso de ajuda eu peço. olha tá indo o dever de casa, precisa lê mais não deixa ficar a toa põe pra estudar em casa, eles me ouvem muito e me ajudam muito também, participam bastante, principalmente no inicio quando eu peguei a turma hoje já ta mais tranqüilo.

7-De acordo com sua experiência, qual a atribuição/valor que os alunos com NEE dão ao espaço escola?

Olha os meus alunos dão um valor enorme a escola eu vejo isso em todos eles, eles adoram vir pra escola, eles gostam de estudar, eles sentem que aqui eles tem o espaço deles. Quando a D está acamada ela fica doidinha, ela me liga pra dizer tia $L$ eu quero fica boa logo pra voltar pra escola logo. Então é assim, eu sinto que eles sentem que aqui é o espaço deles, eles são acolhidos, onde eles estão crescendo, tudo isso rola aqui, então eu acho muito legal sabe? Eu tô no paraíso aqui (risos) eu gosto muito do que eu faço e vejo que os meninos estão satisfeitos, estão crescendo, estão evoluindo e eu acho isso muito legal.

\section{8-Como é a relação dos demais alunos com seu aluno com NEE?}

Aqui na escola já, como nessa escola tem um histórico de inclusão, tanto a família dos alunos, como os alunos que não são NEEs que estão nessa escola têm um bom relacionamento com os ANEE, sabem respeitar, eles ajudam muito, ás vezes tem um muito perdido aí que vão beber água e se perdem, traz o aluno ou a $L$ mesmo que é do ensino especial ela pega o aluno traz o ele pra mim, eles se ajudam muito eu acho muito bacana isso aqui, ás vezes eu vejo colegas minhas dizendo que os alunos são isolado, são rejeitados, são chacoteados, graças a Deus isso não acontece isso a direção ela é muito eficiente que como ela tem uma parte assim, a gente trabalha muito valores no 
inicio do ano e no ano passado também e nesses valores a gente trabalha essa coisa de valores que precisa ajudar o outro então isso que está mio que contido nessa crianças que estão aqui e a própria família que tem filhos aqui sabe que aqui é uma escola inclusiva e prezam esses valores também, eu acho que isso tem muito a ver. Mas não é só aqui não eu vejo lá na escola parque eles vão para a escola ele fala nossa tia os meninos gostam muito de mim lá e eles ficam até assim espantado de ver as potencialidades dos meninos, principalmente $o$ os deficientes visuais quando para pra conversar com as crianças eles vem que as crianças tem um potencial incrível e que pode ter uma troca que as vezes o desconhecido faz com que se afaste, eu acho muito legal isso.

9-Diga quais foram as maiores dificuldades no processo de inclusão aqui na sua escola, bem como os avanços conquistados.

Olha fica difícil pra mim falar do processo de inclusão aqui na escola porque eu participei do processo de inclusão como itinerante, há quatro, cinco anos quando eu atendi essa escola, mas ela já é tradicionalmente inclusiva há muito tempo, então o que a gente tá colhendo hoje já foi plantado há muito anos. Os professores que vem pra cá sabem que vão encontrar alunos com necessidades especiais, a direção é uma direção que ajuda tanto no sentido de dá material, dá apoio, quando eu cheguei aqui nessa escola eu precisei de muitos materiais eu só cheguei na direção e falei eu preciso disso, disso...disso, dois dias estava tudo comprado, tudo na minha mão. Eu precisei fazer curso no Rio de janeiro a direção me apoiou, acatou a minha ida, arrumou substituto pra mim, então esse apoio da direção é muito legal sabe? Porque a direção é inclusiva também sabe? Faz toda diferença. Eu acho que tem que ser uma coisa do porteiro ao gestor, os servidores também ajudam, eles são os xodozinhos da escola, meus alunos aqui, as merendeiras tem um maior carinho com eles,tem o maior cuidado com eles, quer dizer eu acho legal isso. Pra falar as possíveis dificuldades eu não saberia falar, as conquistas eu acho que é isso não é de estar acontecendo, tem problemas tem, mas eu acho como tudo tem problemas você precisa tá revendo eu acho porque a gente tem que ter compromisso de sempre tá melhorando, a gente tem, né? Então é por aí.

10-Em sua opinião, o que precisa ser feito para termos uma educação efetivamente inclusiva?

Aí eu acho que isso ai você vai partir pra uma coisa mais nacional, por exemplo, os meus alunos com dificuldades na hora do transporte, eu tenho muita preocupação com o X porque a mãe quer tirar e levar pra a cidade que eles moram e eu não sei se ele vai ter lá o mesmo suporte que tem aqui né! Eu já falei pra ela que eu quero conhecer a escola pra onde ele vai porque ele foi mal alfabetizado é um aluno que precisa de um amparado pra poder realmente ter um desempenho legal, então se tirar daqui jogar numa escola que o 
professora não sabe Bráulio, não tem uma sala de recursos que vá produzir o material em Bráulio pra ele, tudo bem ele tem a maquina dele tem, mas isso não é o suficiente pra ele, ele precisa de um material escrito, ele precisa de um sorobã, ele precisa de um professor pra sala de soroban, então eu acho que tudo isso tem que ser feito. Em nível nacional a gente não tá com os nossos investimentos, quem tá lá em cima tem que pensar tem que ter investimentos tanto na área profissional como na área material. Eu acho que tem que ter investimento na inclusão é um direito dessas crianças, agora também cabe a nós professores da sala de recursos conscientizar os pais desses alunos, eu acho que eles tem muito mais poder do que eles pensam, logo que eles correm atrás eles conseguem as coisas mais do que nós professores, então eu acho que por aí os estado só faz quando é cobrado e por isso que acabaram com a itinerância né porque qual era o papel do itinerante, além de puxar a orelha do diretor e da escola que não estava fazendo um bom trabalho ele dava um suporte porque o papel do itinerante era esse de dá suporte, mas também de cobrar ele também instruía a família como cobrar e isso incomodava o que acontecia muitos pais iam para o ministério, ganhavam as causas e eles eram obrigados a atender e isso incomodavam. Hoje mesmo no curso que eu faço sobre soroban a gente tava discutindo sobre isso que um colega lá disse que eles vão acabar com a sala de apoio dele no ano que vem, isso lá na regional dele e ele muito ansioso com relação a isso e falando que foi uma pessoa que foi eleita agora e que vai terminar que tá querendo acabar com a sala de recursos e a gente comentando enquanto a gente não tiver pessoas politicamente comprometidas com a educação e com o processo de inclusão pelo menos conheçam, saibam o que é. Do que esses meninos precisam, não adianta porque o diretor da regional fez isso. Gente! o diretor da regional tem que entender da inclusão, tem que fazer parte desse processo e os pais também tem que cobrar mais isso porque não é só ser costas quentes que colocou lá.

\section{Entrevista 5 - Com a família (mãe) do aluno com NEE}

1- Qual é a importância do espaço escolar na vida de seu filho com NEE?

Então o espaço escolar pra mim é muito importante e pro $M$ também até porque assim depois que ele começou a escola normal ele desenvolveu bastante, desenvolveu bastante, ele é muito carinhoso, ele é muito dado, ele se enturma muito bem com todos os amigos, com o professor, com todo mundo. Ele é muito carinhoso então esse espaço pra mim desenvolveu bastante ele em relação ao tudo é o crescimento, o espaço com os amigos, os amigos todos gostam do $M$ então a escola pra mim é muito importante e desenvolveu bastante e eu agradeço muito assim principalmente é do lado da minha casa, que eu moro aqui na $\mathrm{M}$ então aqui eu trago, as vezes eu passo deixo o $\mathrm{M}$ ele 
vem eu deixo ele vim sozinho, mas eu fico olhando! Sempre tem um porteiro uma porteira pra esperar, então isso é muito importante. Essa escola aqui o espaço dela é pequeno, mas é aconchegante.

\section{2- Para você e para o seu com NEE a escola representa o quê?}

É então, como eu falei, ele tem Síndrome de Down, então o desenvolveu social foi muito importante o meu desejo que eu desejo para meu filho é que ele se alfabetize que ele aprenda a ler e a escrever que ele tem dificuldade de audição e de fala então pra ele fica muito difícil tudo ele conhece todas as letrinhas, mas ele não consegue assim sabe desenvolver um redaçãozinha mesmo que pequena e isso me deixa muito ansiosa o que eu gostaria mesmo que o meu filho, pra vida dele mesmo é que ele conseguisse desenvolver na leitura e na escrita. E tem uma agenda muito grande tem a professora de recursos a professora dele até hoje foram poucas que não foram boas todas sempre se dedicam bastante elas fazem o máximo porque é devagar mesmo.

3- Como a escola promove a participação da família no processo de aprendizagem de seu filho?

Então! Eu sempre tô em reuniões, mesmo sem convocar eu sempre estou com as professoras dele, eu venho deixar e venho buscar, então a gente se encontra e eu pergunto como que foi o dia ele tá se tem alguma coisa pra corrigir teve um dia que ele foi para o recreio e não queria voltar ai eu falei pode deixar que eu converso com ele porque se ela me fala se eu sei do que tá acontecendo fica mais fácil porque eu converso com ele em cãs a e o $\mathrm{M}$ entende tudo, tudo, tudo. Esse espaço a escola abre mesmo eu to sempre com a professora da sala de aula e da sala de recursos eu venho buscar o $\mathrm{M}$ eu fico mais de 20 minutos com a professora da sala de recursos a gente fica conversando até mesmo que ela tem um filho com Síndrome de Down ai a gente conversa muito sobre isso.

4- Como a família participa da vida escolar de seu filho com NEE?

Por exemplo, quando tem festinha, festinha da família, festinha de final de ano, festinha de páscoa, sempre as minhas filha estão; sempre, sempre. Ou vem o namorado com elas então sempre é uma turma sempre a gente tá junto aqui.

5-Quais são as maiores dificuldades enfrentadas pela família ao trazer o aluno com NEE para a escola?

Até o momento graças a Deus a gente não teve dificuldade nenhuma porque eu moro ao lado da escola, sempre morei aqui sempre morei a aqui e quando ele estudava na outra escola é perto e eu levava de carro, então sempre morei perto da escola então nunca tive dificuldade não teve dificuldade nenhuma, meu filho anda graças a Deus. 
6-Em sua opinião, quais foram (ou são) as maiores dificuldades encontradas no processo de inclusão escolar de seu filho e quais foram os avanços conquistados?

Teve, assim teve muito avanço, mas teve, teve muita dificuldade tem até hoje, porque é assim a turma é grande o $\mathrm{M}$ tem muita dificuldade. A turma é grande parece que tem 29 alunos o $\mathrm{M}$ tem muita dificuldade parece que turma são 3 ou 4 crianças especiais. Então a professora fica difícil porque cada um com a sua dificuldade. São 3: tem o $\mathrm{H}$, tem o $\mathrm{M}$ e tem a $\mathrm{J}$ que tem problema de visão. Então para a professora fica difícil ela tá na turma sozinha o certo era, seria um monitor para, por exemplo, quando ela tá passando a matéria normal, a monitora estaria fazendo uma adequação com os outros, e mesmo assim a adequação do $\mathrm{M}$ é diferente do $\mathrm{H}$ né? Então fica difícil tem que trabalhar ainda muito isso na escola. Mas melhorou bastante, quando meu filho entrou na escola tinha professor que nem sabia o que esta Síndrome de Down ele teve que correr atrás, procurar porque na época a fundação não dava curso hoje em dia ta assim tem muito curso para professor, antigamente não tinha, então ás vezes o professor tinha que correr atrás. Ė um avanço! Tem que avançar mais tem, mas já deu um a melhorada. O governo mesmo propôs um monitor dois professores na sala de aula, um curso especifico para o professor se "especificar" cada vez mais eu acho que é assim né? e elas já estão fazendo isso já tá correndo atrás eu acho que é a tendência é sempre melhorar eu acho que vai melhorar. Principalmente aqui na nossa escola aqui é muito boa, tem imas que tem um déficit maior aqui tá mais estruturado.

\section{Entrevista 6 - Com a família (mãe) de aluno com NEE}

1-Qual é a importância do espaço escolar na vida de seu filho com NEE?

Ah é muito importante porque aqui ele aprende, se desenvolve tem outras crianças com o mesmo problema, então eu acho muito importante é isso, a escola ajuda é muito.

\section{2- Para você e para o seu filho com NEE a escola representa o quê?}

Ah! Representa muito na vida dele, sem a escola eu nem sabia como seria a vida dele, seria muito difícil. Ele gosta de vir para a escola? Virge! Adora! A coisa melhor que ele acha nunca mata um dia de aula mais é importante de ir pra escola pra ele é a coisa mais importante, que ele mais gosta é de estudar, apesar de aprender muito pouco. Ele fica um período na escola? É fica um período. Tem outras atividades fora da escola? Tem uma aula de música que aqui dando, tem natação. No mesmo horário? Não horário diferente. Tem aula em outra escola que é com a fonoaudióloga que é no CEE. As professoras dele cada uma é mais maravilhosa que a outra e isso é muito importante. 
3- Como a escola promove a participação da família no processo de aprendizagem de seu filho?

Ajudando a desenvolver a descobrindo o problema que ele tinha que nem eu sabia e eles me ajudaram a descobrir aí pra mim foi muito importante porque se eles não tivessem me ajudado até hoje eu não sabia. Ele tem dislexia também ele tem DEPAC, ainda então era muito difícil ele estudava, estudava e ele nunca aprendia nada e eu não sabia por que. Aí a professora $C$ falou que eu fizesse uns exames de neurologia pra ele eu fui e descobri os problemas que ele tinha todos. A família aqui na escola é importante demais porque se não fosse ela o que seria dele, ele não tinha nem como desenvolver e ele tá desenvolvendo demais. Eu to até admirada como eu to surpresa com ele.

4-Como a família participa da vida escola de seu filho com NEE?

A família sou eu mesmo né? Sou eu que levo, ajudo da maneira que eu posso porque não tem mais ninguém só sou eu e ele. Sempre conversando com a professora, quando tem reunião, tudo que passa, elas me informam. Já tive muita briga também porque a professora dizia que ele não aprendia porque ele era bagunceiro, mas eu não sabia que ele tinha problema, depois que eu fui saber. Aí eu vi que não era culpa dele porque quando a gente não sabe ler o que faz dentro de uma sala? Bagunça! Porque você não entende o que a outra pessoa fala, depois que ele passou a entender tudo acabou-se as confusão.

5- Quais são as maiores dificuldades enfrentadas pela família ao trazer o aluno com NEE para a escola?

Uai! É muito difícil você trazer, as vezes você não tem nem condição, mas tem que se fazer o possível e o impossível pra trazer e manter ele aqui né? No meu caso eu não moro perto eu moro no $P$ Norte, eu pego duas conduções de ida e duas de volta e ele caminha 20 minutos de á pé, mas é muito difícil, mas pra mim não é problema, a distancia não é problema por ele eu faço qualquer coisa. Por que escolheu essa escola? Ah! Porque essa escola é da inclusão, tem outras crianças que tem problema igual a ele. Seria muito mais fácil pras outra era mais difícil. E no $P$ Norte não tem outra escola? Eu não sei por que ele está aqui desde os 6 anos, então aqui é ótimo pra ele é maravilhoso.

6- Em sua opinião, quais foram (ou são) as maiores dificuldades encontradas no processo de inclusão escolar de seu filho e quais foram os avanços conquistados?

Ah eu acho o problema que ele mesmo se sente muito inferior, por ele não aprender a ler ele se sente muita dificuldade, a idade dele ele tem vergonha criança mais nova e sabe ele mesmo é que eu nem sei o que falar ele fala ah mãe eu tenho tantos anos eu tô na terceira serie ainda eu pra tá mais... mas filho nem todo mundo é igual você não pode ser igual a eles, você sabe ler, 
você se desenvolve, você vai se formar, mas é tudo no seu tempo e na sua hora e a professor $\mathrm{C}$ ajuda demais da conta ela foi muito importante. E quais foram os avanços nesse processo de inclusão? Até o ano passado ele não sabia ler nenhuma palavra. Esse ano já sabe ler, já sabe escrever. Nossa ele se $\mathrm{S}=$ desenvolveu demais da conta foi maravilhoso. E a questão você disse que no inicio as crianças rejeitava? É porque ele não enxergava de um olho e as crianças falavam que ele era um cego, aí ele ia lá dava um murro e dizia ver como eu sou cego, se eu não enxergo. Aí fiz uma cirurgia, corrigi o olhinho dele aí tudo melhorou, graças a Deus!

\section{Entrevista 7 - Com a família (mãe) de aluno com NEE}

1-Qual é a importância do espaço escola na vida de seu filho com NEE?

Olha eu acho que o espaço escolar tem uma importância muito grande para que o deficiente cresça no meio da sociedade. Já que você falou em sociedade depois da escola o que você espera do seu filho? Bom eu quero que ele tenha um emprego e siga a vida dele, né? Case, tenha os filhos dele, faça faculdade, tenha uma vida normal igual os demais.

2-Para você e para o seu filho com NEE a escola representa o quê?

Olha! A escola é muito importante na vida do meu filho. Por quê? Porque ela dá todo o apoio que ele precisa para que ele cresça cada vez mais.

3-Como a escola promove a participação da família no processo de aprendizagem de seu filho?

A escola ela interage com os pais, tem um vinculo muito grande com os pais, principalmente a escola classe aqui. Ela tem um vinculo muito grande com os pais, então ajuda muito também na aprendizagem dele.

4-Como a família participa da vida escolar de seu filho com NEE?

A minha família todas as pessoas, cada um da minha família tem um jeito de pensar diferente e tem uns que pensam que ele não vai pra frente porque ele é deficiente visual, o outro não, ele vai sim! Então quer dizer eu coloco na cabeça de todos que ele é uma pessoa normal. Como se dá essa participação em relação a escola? Como você participa? Bom eu participo de todos os momentos da vida de meu filho na escola, trago, fico esperando ate ele sai, levo ele pras outras escola, que dizer para outras atividades e sempre acompanho.

5-Quais são as maiores dificuldades enfrentadas pela família ao trazer o aluno com NEE para a escola? 
Eu já falo que é a distância né? Porque a gente mora lá na Ceilândia e tem que pegar às vezes dois ônibus, às vezes o ônibus não passa na via e tem que subir lá pro eixo, então é muito difícil. Ônibus lotado, o governo não dispõe de condução para deficiente, não põe uma escola mais próxima que tenha professores capacitados para lhe dá com deficiente visual.

6-Em sua opinião, quais foram (o são) as maiores dificuldades encontradas no processo de inclusão escolar de seu filho e quais foram os avanços conquistados?

Eu acho que é... assim, as dificuldades dele, minha ou sé dele? Tudo. Eu acho que a inclusão que o governo fala que tem não e uma inclusão que a gente pensou que ia ser. O governo fala: Vamos incluir! O que é inclusão? Inclusão não é os deficientes interagir com os outros alunos como todos fossem iguais. Mas na verdade ainda tem preconceito por parte dos outros alunos. Eu não conheça professor que tenha preconceitos, mas pode haver em algum lugar.

E os avanços conquistados você consegue citar algum avanço nesse processo de inclusão? Consigo sim! Meu filho depois que veio para esta escola ele teve três professoras, só uma conseguiu alfabetizá-lo. É. só uma professora pegou no pé mesmo e em três meses ele tava lendo o Braille e em cinco meses ele tava escrevendo. Aí eu comprei a máquina, aí que veio o interesse da minha parte, que eu não queria comprar a máquina, aí me esforcei e comprei a máquina de Braille dele.

\section{Entrevista 08 - Com a família (mãe) de aluno com NEE}

1- Qual é a importância do espaço escolar na vida de seu filho com NEE?

Bom eu achava que seria importante pra ele um espaço bonito, organizado, tranqüilo, mas eu descobri que a simplicidade do espaço é melhor pra eles, eles se sentem mais aconchegado, mais abraçados mais em casa.

2-Para você e para o seu filho com NEE a escola representa o quê?

Representa um momento de interação, de socialização ele se sente muito feliz, mesmo quando ele está febril ele pede me dar remédio que eu não posso faltar então isso me mostra que pra ele isso muito importante que ele gosta muito ele já cresceu muito na escola já amadureceu já se socializou demais.

3-Como a escola promove a participação da família no processo de aprendizagem de seu filho? 
Ela promova através de reuniões, de reuniões bimestrais, se colocam o material que foi utilizado até então, e colocam relatórios sobre observação que fizeram feito com aluno em todas as áreas.

4- Como a família participa da vida escolar de seu filho com NEE?

É a família apóia, incentiva, mas o contato maior é com a mãe comigo, fazendo dever de casa com ele, ele não gosta de fazer dever de casa muito não, como todo adolescente, mas participamos através das reuniões e das festas escolares fazemos questão de ir mostrando pra ele qual é a importância pra nós.

5-Quais são as maiores dificuldades enfrentadas pela família ao trazer o aluno com NEE para a escola?

As maiores dificuldades, bem no inicio foram porque eu achava que a escola particular seria melhor bati cabeça e ele dava patente não queria, enfim só consegui colocar meu filho por opção minha no colégio da rede pública aos 11 anos ele tinha 11 anos quando ele entrou e foi uma bênção pra ele porque em 6 meses ele já estava lendo, escrevendo e interagindo, e se soltando, passeando com escola enfim pra ele as dificuldades maiores foram enfrentadas pela família quando ele estava num colégio particular que não era o lugar dele na rede eu enfrentei muitas poucas dificuldades.

6-Em sua opinião, quais foram (ou são) as maiores dificuldades encontradas no processo de inclusão escolar de seu filho e quais foram os avanços conquistados?

Bom incluído ele ainda não estar ele está numa sala especial com quatro alunos, duas professoras, numa escola de 1 a 4 séries numa escola inclusiva, ele fez alguns momentos de vivencia a dificuldade foi essa ele teria que passar pelos momentos de vivência pra entrar e ser incluído numa sala mas eu acho que eu pequei também quanto a esses a momentos primeiro porque ele tem dificuldade de acordar pela manhã tomando medicação controlado que dar muito sonos e eu tentava que ele chegasse no horário e ele ficou assim chegando mais atrasado ate que parou-se os momentos de vivência no ano passado e esse ano começo mas foi algo assim, que eu achei que avaliaram rápido e já acharam que ele não seria adequado pra ele a inclusão em sala não sei as vezes eu acho que começou acompanhado desde o início e observando eu acho que faltou um pouquinho de boa vontade, tanto da sala da professora na sala inclusão e de repente ate um joguinho de cintura da própria professora não sei ambas foram dedicadas aparentemente, mas eu acho que não sei eu sei que em reunião com equipe rede foi falado que observando-se 34 idas dele no momento de vivencia já sentiam-se ele realmente teria o perfil com a inclusão e sentiram que não pela interação pelo emocional, enfim vamos aguardar. 
Os avanços foram muitos. Igor hoje é outra pessoa, ele hoje conversa, tem um vocabulário grande, domina o computador, não pela escala porque lá ele quase não usou o computador, acho que nem usou, mas em casa devido essa interação e socialização a auto estima dele subiu muito então ele aprende com mais facilidade domina, baixa sites, entra em sites, baixa jogos, enfim joga, navega na internet acompanha programa de TV, acompanha campeonato de futebol, de automobilismo pela internet, imprime lista, enfim hoje eu sinto ele muito mais feliz com essa escola pra ele foi muito importante.

\section{Entrevista 09 - Com o aluno com NEE}

Idade: 12 anos

Quantos irmãos você possui: 01

Qual a deficiência: Dislexia e DEPAC

1- É bom estudar nesta escola:

$(x) \operatorname{Sim} \quad($ ) Não

2-Você gosta da hora do intervalo (recreio):
( $x) \operatorname{Sim}$
( ) Não

3-Seus colegas ficam com você na hora do intervalo:
( $x) \operatorname{Sim}$
( ) Não

4- Seu professor facilita a sua participação nas aulas:
( $x) \operatorname{Sim}$
) Não

5- Quando você necessita de alguma ajuda solicita a quem:
(x ) Professor
( ) Colega
( ) Monitor

6- O que você faz na hora do recreio?

Eu fico jogando jogo de carta baralho. Com quem? Com os meus amigos. São quantos? Tem que ser cinco pessoas, são quatro. Toda vez você faz isso? Toda vez. Tem outra atividade que você faz na hora de recreio? Jogar bola.

7- Com quem você vem para a escola?

Com minha mãe. Às vezes sozinho. Às vezes sozinho! Você mora aonde? Eu moro Ceilândia. E você vem só? Sozinho. 
8- O que você mais gosta de fazer na escola? Eu! É brincar, estudar também. E o que menos gosta? Ficar correndo porque na hora que chegar na sala fica com preguiça de fazer o dever porque fica cansado.

9- Você acha muito importante vir à escola? Sim Por quê? Pra gente ter um aprendizado bom. È aprender... brincar. Seus amigos estão aqui ou na sua rua. Tão mais aqui.

\section{Entrevista 9 - Com o aluno com NEE}

Idade: 10

Quantos irmãos você possui: 02

Qual a deficiência: DTAH

1- É bom estudar nesta escola:
( $x) \operatorname{Sim}$
( ) Não

2-Você gosta da hora do intervalo (recreio):
( $x) \operatorname{Sim}$
( ) Não

3-Seus colegas ficam com você na hora do intervalo:
$(x) \operatorname{Sim}$
( ) Não

4- Seu professor facilita a sua participação nas aulas:

( $x$ ) Sim ( ) Não

5- Quando você necessita de alguma ajuda solicita a quem:
(x) Professor
( ) Colega
( ) Monitor

6- O que você faz na hora do recreio?

Brinco. Brinca de quê? Brinco de policia e ladrão, brinco de várias coisas. Com todos os colegas? Ou tem alguns que você escolhe? Não nós brinca com todos. Mas, um vai saindo e vai entrando outro. Eu gostaria que fosse um pouco maior o intervalo.

7- Com quem você vem para a escola?

Com minha mãe.

8- O que você mais gosta de fazer na escola? Estudar! E o que menos gosta? Nada. Tudo que tem na escola você gosta? É 
9- Você acha muito importante vir à escola? Sim. Por quê? Pra mim, crescer e ter um bom emprego, ter um emprego no futuro. Ter um emprego garantido. Né?

\section{Entrevista 11 - Com aluno com NEE}

Idade: 13 anos

Quantos irmãos você possui: 02

Qual a deficiência: Deficiência Visual e TDAH

1- É bom estudar nesta escola:

( $x$ ) Sim ( ) Não

2-Você gosta da hora do intervalo (recreio):

$(x) \operatorname{Sim} \quad($ ) Não

3-Seus colegas ficam com você na hora do intervalo:

$(x) \operatorname{Sim} \quad($ ) Não

4- Seu professor facilita a sua participação nas aulas:

$(x) \operatorname{Sim} \quad($ ) Não

5- Quando você necessita de alguma ajuda solicita a quem:
( $x$ ) Professor
( ) Colega
( ) Monitor

6- O que você faz na hora do recreio?

Eu brinco, eu converso é hora que eu tenho pra brincar com meus amigos e me divertir, ás vezes eu falo assim, quando um brinca eu digo não pode não pode ser assim quando a menina da brincando com outra aí eu falo assim não pode não pode brigar.

7- Com quem você vem para a escola?

Com a minha mãe.

8- O que você mais gosta de fazer na escola?

Estudar, ler e escrever. E o que menos gosta? Ás vezes é do lanche, às vezes é bom, às vezes não é.

9- Você acha muito importante vir à escola?

Acho Por quê? A gente aprende mais a ler e escrever do que ficar naqueles negócios de criminalidade, aquelas coisas. 